\title{
Fungal cardiomyopathy: A review and pooled analysis of pathophysiology, diagnosis and clinical management
}

\author{
Aref Albakri* \\ St-Marien hospital Bonn Venusberg, Department of Internal Medicine, Bonn, Germany
}

\begin{abstract}
The incidence of invasive fungal disease has dramatically increased over the past few decades corresponding to the rising number of immunocompromised patients - mostly those with Human Immunodeficiency Virus (HIV)/Acquired Immunodeficiency syndrome (AIDS) and cancer. The major risk factors for severe cardiac fungal disease are prolonged administration of antibiotics, corticosteroids and cytotoxic agents, invasive medical procedures, and transplant recipients. Invasive fungal infection often affects multiple organs and cardiac involvement frequently occurs in disseminated disease. Ante mortem diagnosis of fungal cardiomyopathy (FCM) is difficult because clinical findings of myocardial involvement are often absent or ambiguous and blood cultures are often negative. Although an uncommon cause of infectious cardiomyopathy (CM), FCM is potentially fatal and thus early diagnosis of the primary infecting fungal pathogen, organs involved and the status of the host immune system is important to guide clinical management. Thus, this paper reviews the major fungal pathogens responsible for CM, clinical setting in which they occur, pathophysiology, diagnosis and management as well as highlights the burden of cardiac fungal infection and the need for additional research to refine current strategies or develop more effective diagnostic and therapeutic strategies.
\end{abstract}

\begin{abstract}
Abbreviations: AGIHO: Infectious Diseases Working Party of the German Society of Haematology and Oncology; AIDS: Acquired Immuno-Deficiency Syndrome; CDC: Centre for Disease Control and Prevention; CFI: Cardiac Fungal Infection; CFI: Cardiac Fungal Infection; CM: Cardiomyopathy; CMR: Cardiac Magnetic Resonance Imaging; CMV: Cytomegalovirus; DCM: Dilated Cardiomyopathy; DCM: Dilated Cardiomyopathy; EORTC: European Organization for Research and Treatment of Cancer; FCM: Fungal Cardiomyopathy; GvHD: Graft-versus-Host Disease; HF: Heart Failure; HIV: Human Immunodeficiency Virus; HLA: Human Leukocyte Antigen; HSCT: Hematopoietic Stem Cell Transplantation; IFD: Invasive Fungal Diseases; IFI: Invasive Fungal Infection; LV: Left Ventricular; MC: Myocarditis; MSG: US Mycoses Study Group; PBSCT: Peripheral Blood Stem Cell Transplantation; RV: Right Ventricular; WHO: World Health Organization.
\end{abstract}

\section{Introduction}

Fungal infections (or mycoses) affect more than a billion people worldwide and are responsible for approximately 11.5 million lifethreatening infections and over 1.6 million deaths annually [1-4]. In contrast, the impact of fungal infection on human health remains the most under-appreciated and under-researched infectious disease. In the U.K., research on fungal infection accounted for less than $3 \%$ of all the funded studies or $1.9 \%$ of the financial investment in all infectious disease research between 1997 and 2010 [5]. The World Health Organization (WHO) has no program on fungal infection, and most public health agencies except the U.S. Centre for Disease Control and Prevention (CDC), conduct little or no mycological surveillance [1]. Although a majority of people in their lifetime will suffer from superficial fungal infection that are easy to cure, millions of individuals worldwide will acquire life threatening invasive fungal infection that are difficult to diagnose or treat. In these patients, infection may spread to multiple organs including cardiac involvement usually in the setting of disseminated fungemia (the presence of fungi in blood), which may result in endocarditis (an intravascular infection), myocarditis (myocardial inflammation) and/or cardiomyopathy (myocardial dysfunction with or without inflammation) [4].

Fungal cardiomyopathy (FCM) in the absence of endocarditis or myocarditis is the most uncommon cardiac complication as well as the least researched of fungal cardiac diseases. Moreover, the epidemiology of FCM is unknown due to the lack of regular national surveillance systems, no obligatory reporting of fungal diseases, poor diagnostic test performance and a paucity of well-designed published studies [6]. However, the incidence of FCM is projected to rise due to a rise in the population of immunocompromised patients, mostly those living with cancer and HIV/AIDS [6,7]. Diagnosis of FCM is further complicated by absent or ambiguous clinical findings of myocardial involvement and usually negative blood culture tests yet early diagnosis and institution of aggressive therapy may improve survival [7]. With increasing numbers of immunocompromised patients, including those on immunosuppressive therapy and transplant recipients, clinical interest on fungal infection of the heart has become manifest in recent years. Thus, the present systematic review and a meta-analysis of published data focuses on causative fungal pathogens, pathophysiology, diagnosis and clinical management of FCM. This paper also illustrates the pressing need for more research in FCM and cardiac fungal infection

${ }^{\star}$ Correspondence to: Aref Albakri, St-Marien hospital Bonn Venusberg, Department of Internal Medicine, Bonn, Germany, E-mail: arefalbakri@yahoo. com

Key words: fungal cardiomyopathy (FCM), cardiac mycoses, cardiac fungal infection (CFI)

Received: January 28, 2019; Accepted: February 25, 2019; Published: February 27,2019 
(CFI) in general, to facilitate the development of better diagnostic tests and therapies.

\section{Fungal infection \\ Definition and history}

Nosanchuk [8] defines FCM as the presence of fungal pathogens in a dysfunctional myocardium with or without inflammation in the absence of any other known cause. However, this definition does not support diagnosis in the clinical setting, which has remained a challenge because cardiac involvement in fungal infection is difficult to diagnose, frequently fatal and mostly discovered at autopsy (post mortem) [8]. Early studies on fungal endocarditis (an intravascular infection) reveal blood cultures are positive in about half $(53 \%)$ of the patients and delayed or incorrect diagnosis occurs in a greater majority $(82 \%)$ of the patients. Prospective investigations determining the incidence of FCM during fungemia are also lacking, nevertheless, autopsy analyses and case reports indicate FMC is a common complication of disseminated fungal infection particularly in immunocompromised patients [8].

The lack of studies on fungal infection may be partly attributed to relative recency of fungal infection. Reports of cardiac infection by fungi were rare in medical literature prior to the 1950s. Description of a patient infected with Blastomyces dermatitidis in the right atrium in 1915 [9], complete documentation of Candida endocarditis in a heroin addict in 1940 [10], Aspergillus mural endocarditis in a child in 1947 [11] and Aspergillus valve endocarditis in a patient with rheumatic heart disease in 1950 [12]. However, since the 1950s, reports of systemic and cardiac fungal infections began to appear with increasing frequency. Autopsy analysis at Johns Hopkins Hospital between 1889 and 1977 histologically confirmed 51 patients with fungal infection of the heart and 34 with fungal myocarditis, all occurring after 1954 [13]. In the 1960s, increased reports of fungal myocarditis in cancer patients particularly haematological malignancies emerged $[14,15]$. Fungal infection of the heart accounted for up to $32 \%$ of the total cardiac infection in patients with acute leukaemia [15]. Reports of cases of fungal cardiac diseases also increased in patients with HIV/AIDS, which ranged between $25 \%$ and $75 \%$ [16-18].

\section{Predisposing factors}

Immune deficiency: The main factors contributing to the rise of fungal infection include: (i) an increase in the incidence of diseases causing immune dysfunction; and (ii) an increase in the medical use of a broad range of antibiotics, cardiac surgery and intravenous use of drugs $[2,4,7,8]$. In particular, two chronic conditions - cancer and HIV/AIDS - have greatly contributed to the increase in the numbers of immunocompromised patients. In the 1950s, clinicians began to recognize a marked increase in the incidence of fungal disease particularly among hospitalized cancer patients [14,19-21]. In 1946, prior to the use of chemotherapy, Craig and Farber [19] did not detect any case of fungal disease in the autopsy of cancer patients at their institution. However, after 1953, they detected disseminated fungal disease in $7.4 \%$ of 175 paediatric patients with leukaemia undergoing cytotoxic and hormonal therapies. In 1955, Zimmerman [20] discovered fungal pathogens that were rarely observed in healthy individuals (such as candidiasis, aspergillosis, cryptococcosis, and mucormycosis) were causing significant disease in cancer patients and associated these mycoses with the use of chemotherapy. In 1962, Baker [22] singled out leukopenia (defined as decreased number of leukocytes in the peripheral blood) as the primary predisposing factor for fatal outcomes in cancer patients diagnosed with invasive fungal infection.
Besides cancer, the epidemic of HIV/AIDS also resulted in a large and unprecedented numbers of immunocompromised individuals. Disseminated fungal infections are relatively frequent in HIV/AIDS patients: Cryptococcosis affects $6 \%$ to $8 \%$ of HIV patients in the United States and up to $30 \%$ of HIV patients in developing countries [23-25]. HIV patients are also at an elevated risk for severe infection by Candida, Aspergillus, Histoplasmosis, Coccidioides, and Blastomycosis [26-30]. Other predisposing conditions to disseminated fungal infection include tuberculosis [31] and primary metabolic disorders such as Cushing's syndrome and diabetes mellitus [32].

Modern therapy: Increased utility of a broad-spectrum of antibiotics and advancements in prophylactic and therapeutic medical procedures in the care of critically ill patients has increased susceptibility of patients to fungal pathogens. As early as in 1950, Zimmerman observed an association between antibiotic use and increased susceptibility to disseminated fungal disease [33] later confirmed by several other studies [34-38]. Other major predisposing factors to severe fungal disease include prolonged ( $>4$ weeks) corticosteroid therapy, intravenous drug use, surgery, bone marrow transplantation and invasive medical procedures, prolonged stay $(>7$ days) in the intensive care unit, and newer immunosuppressive agents [8,24,39-41]. There are also reports of the presence of fungal infection in immunocompromised patients without signs and symptoms of conditions associated with immunocompromised status [42,43]. Technological advancements in the care of critically ill patients including very low birth weight infants are common trends in wellequipped clinical facilities. These advancements increase infant and patient survival rates while increased use of prophylactic antibiotics, prosthetic devices, hyper-alimentation and organ/bone marrow transplant predispose patients to a variety of fungal infections [6]. Reported cases of Candida infection in neonates and outbreaks in neonatal intensive care unit are increasing. Other non-medical factors such as newer land use activities, travel, and commerce may promote the emergence of fungal infection in immunocompetent individuals who were previously unexposed to fungal infection [6].

\section{Fungal pathogens (Disease)}

Fungal infection can be primary (infecting healthy individual previously unexposed to endemic fungi) or opportunistic (infecting immunocompromised individuals). Primary infections have a favourable prognosis while opportunistic infections have an ominous prognosis with higher mortality rates. The most frequently diagnosed opportunistic invasive fungal infection of the myocardium are those due to Candida, Aspergillus and Cryptococcus [44]. Others are dimorphic fungi such as Histoplasma, Blastomyces and Coccidioides [1]. These fungi are ubiquitous, usually acquired from host surroundings (Cryptococcus neoformans, Aspergillus fumigatus) or are components of the normal endogenous flora (Candida albicans) [45]. The mortality of the infected patients remains unacceptably high even after intensive antifungal therapy attributed to the patient's immunodeficiency, belated diagnosis or fungal disease resistance [46].

\section{Candida (Candidiasis)}

The genus Candida includes more than 200 ascomycetous yeasts with Candida albicans believed to be the major opportunistic fungal pathogen in humans. Candida can colonize the skin and mucosal surfaces of healthy people and occurs commensally in the gastrointestinal tract, oral cavity and vagina causing superficial infections [47]. Candida can enter the bloodstream by direct penetration via damaged epithelial tissue or by dissemination from biofilms formed on medical devices 
introduced into the patient's body such as catheters, dental implants, endoprostheses, artificial joints or central nervous system (CNS) shunts [47,48]. In the blood, Candida disseminate with the circulation and can infect multiple body organs including lungs, kidney, heart, liver, spleen and/or brain causing fungemia and life threatening septicaemia. Cardiac candidiasis occurs as a consequence of disturbed balance between host immunity and opportunistic Candida infection [46] Cardiac candidiasis is not only the consequence of immunodeficiency of the host but also the ability of Candida to adapt to new niches dependent on the expression of infection-associated genes [49]. These genes, and their products, contribute to fungal pathogenicity and are described as virulence factors. In the case of Candida, the major virulence factors are the production of different hydrolytic enzymes and adhesins. Other factors influencing virulence include the ability to form biofilms on various surfaces, to change morphological form and to switch between various phenotypes [50].

Although published evidence on Candida CM are conspicuously lacking, research reports on Candida MC provide a valuable insight into the incidence, pathophysiology and diagnosis of Candida CM since it is a sequela of myocarditis. The association of Candida infection with fungal MC and its sequela, dilated cardiomyopathy (DCM) with immunodeficient patients is relatively recent. Prior to the routine use of cytotoxic and immunosuppressive medications, reports of myocardial candidiasis were rare $[12,38]$. In a review of 1402 autopsy cases of histologically confirmed MC, Gore and Saphir [51] did not find any case of candidal cardiac involvement. In the 1960s, autopsy studies identified a significant increase in the incidence of cardiac candidiasis in cancer patients [14,52]. In 1968, autopsy analysis of 420 hearts of patients who died of acute leukaemia, $1.4 \%(n=6)$ had Candida MC [15]. Another autopsy study on 85 cancer patients with disseminated candidal infection performed in 1978 found 20\% ( $\mathrm{n}=17)$ had Candida MC including other organs involvements such as kidneys, gastrointestinal tract, lungs, liver and CNS in a majority of the patients [53]. Detection of Candida myocardial abscesses is based on microscopic evidence of the presence of numerous pseudohyphal and yeast forms involving tissues with central zones of necrotic cardiomyocytes and mononuclear infiltrates $[21,15,53]$. The extent of inflammatory reaction varied based on the immune status of the patient, with the absence of neutrophils and dense fungal growth occurring in patients receiving high doses of cytotoxic or immunosuppressive agents compared to intense inflammatory reaction with fewer organisms in patients not taking these medications $[13,54]$.

Disseminated Candida infection resulting in myocardial infection are also common in patients who have undergone surgery. In autopsy analysis of 14 surgical patients, 13 had evidence of disseminated Candida infection with MC. All the 13 patients had central venous catheters, 12 had undergone major surgical procedures, and all received multiple antibiotics. Multiple organs (kidney, brain and eyes) were involved in a majority of patients [55]. In a review of autopsies between 1959 and 1974, 50 patients had evidence of disseminated Candida infection. These patients had significant medical illness (malignancy, autoimmune disorders and/or bacterial infection), had recent surgical procedures (25) and received antibiotics (27), corticosteroids (16) and antineoplastic drugs [9]. Of the 50 patients with systemic candidiasis, $62 \%$ had histological evidence of Candida MC, in whom myocardial abscesses varied in size and number and inflammatory reactions ranged from complete lack of inflammation to acute suppuration with coagulative necrosis of cardiomyocytes [54]. Walsh et al. [13] identified 34 patients with fungal MC at autopsy and Candida infection accounted for $71 \%$ of the patients. Pathologic findings ranged from micro abscesses to grossly visible lesion and necrotic myocardium. Risk factors included chronic antibiotic therapy, gastrointestinal surgery or corticosteroid administration. In two separate autopsy analyses of 8,975 and 3,601 patients, 18 and 15 patients respectively had Candida MC with the involvement of the kidney and/or the brain. Risk factors were medical use of antibiotic, antineoplastic, or steroid therapy [56,57].

The pathogenesis of Candida infection of the myocardium and the development of MC or DCM remains an understudied topic. Direct extension of the valvular candidal vegetation into the myocardium has been proposed as well as discrete myocardial abscesses corresponding to haematogenous seeding. Myocardial abscesses can extend and involve the endocardium or the pericardium [58,57]. Clinically, Candida myocardial infection is frequently asymptomatic. Electrocardiographic (ECG) abnormalities are common but they are non-specific because they are not significantly difference from those of other critically ill patients without $\mathrm{MC}$ or from patients with candidiasis without cardiac infection [53,56,59]. Franklin et al. [54] evaluated 31 patients with MC and found ECG evidence of conduction perturbations, supraventricular arrhythmias, QRS abnormalities consistent with myocardial infarction, and significant T-wave abnormalities. ECG evidence of a complete atrioventricular block in a patient with acute myelomonocytic leukaemia with C. albicans in the HIS bundle has also been described [60].

\section{Aspergillus (Aspergillosis)}

Aspergillus is an ascomycetous saprophytic and ubiquitous fungus responsible for moulding. It is found worldwide and are abundant in the environment. Airborne Aspergillus are inhaled by everyone because of their high concentration as well as are frequently present in food especially pepper and tea, in tap water, at home and in office rooms, which explains its high prevalence in community acquired infection particularly in the immunocompromised and immunocompetent individuals $[46,61]$. Patients with severely compromised immunity may contract life-threatening invasive pulmonary disease or disseminated infection. A high mortality rate $(60 \%$ to $90 \%)$ is correlated with late diagnosis and relatively poor knowledge about fungal pathogenicity and virulence factors $[62,63]$. However, the pathogenic role of some features of Aspergillus believed to be putative virulence factors including heat tolerance, adhesins, pigment production, toxic metabolites and extracellular enzymes that evolved as fungal protection against adverse environmental conditions remains unclear [64]. The functions and character of the putative virulence factors of Aspergillus are still under investigation but it is believed there is a substantial cooperation between these factors, many of which are regulated by genes. Thus, it is not possible to indicate clearly, which of these factors contribute to the mechanism of pathogenesis [46]

Despite the lack of a complete understanding on the mechanism of Aspergillus infection in the myocardium and the development of MC and/or CM, accumulating evidence suggests it may be an important aetiology of FCM. Disseminated disease after invasive Aspergillus infection is prevalent in immunocompromised patients and associated with an unacceptably high mortality rate of up to $84 \%[65,66]$. Aspergillus myocardial infection is relatively recent. In a 1942 review of medical literature on MC [67] and 1947 autopsy analysis of 1402 cases of MC [51], there were no reported cases of Aspergillus CM. Since the 1950s, numerous reports of cases of invasive Aspergillus infection with myocardial involvement and MC have emerged [13-15,41,58,,68,69]. The increase in the cases of invasive Aspergillus infection of the 
myocardium correlate with the frequent use of chemotherapy drugs, immunomodulators, antibiotics and invasive procedures $[8,46]$. The initial recognition of leukopenia as the primary cause of fatal Aspergillus infection was in 1962 [22]. Subsequent studies confirmed this finding prolonged granulocytopenia due to intensive chemotherapy $[70,71]$ and increased incidence of severe aspergillosis in cancer patients [72,73].

Typical histological appearance of Aspergillus myocardial infection is abscesses (focal or diffuse) containing septated hyphae associated with necrosis and infarction [13,74-76]. Other common pathological features include mycotic thrombosis of cardiac vessels consistent with fungi predilection for vascular structures and neutrophilic inflammatory response but which may be absent in severe neutropenia, and hyphae may extend from the thrombosed vessels into the necrotic myocardium $[13,73,76,77]$. Risk factors for Aspergillus cardiac infection include cytotoxic drugs, immunosuppressive drugs, steroids, radiation, leukopenia, antibiotics, cardiac surgery particularly valve replacement, chemotherapy, corticosteroids and renal disease [58,76]. Aspergillus myocardial infection may be suspected in patients with endocarditis and HIV/AIDS patients. Aspergillus is the second leading cause of fungal endocarditis after candidiasis [68]. In 16 patients identified with Aspergillus MC, myocardial was involved in 10, myocardium and endocardium in five and myocardium and pericardium in two [57,58]. Although HIV/AIDS patients are at a higher risk for invasive Aspergillus infection, relatively few reports exist [8]. In 37 cases of invasive Aspergillus in AIDS patients, only 14\% had myocardial infection [27].

The pathophysiologic mechanisms of Aspergillus infection and the development of CM maybe multifactorial but the exact mechanisms remain loosely understood. The main portals of entry for Aspergillus include respiratory tract, damaged skin or other wounds, the cornea and the ear. Infection via the gastrointestinal tract is possible but not clearly documented. A greater majority of the patients (80\%) have pulmonary disease [65]. Myocardial infection by Aspergillus typically occurs by direct extension from the lungs. The fungi infects the pulmonary vessels, moves to infect the endocardium and subsequently involves the myocardium $[73,78,79,80]$. Infected cardiac valves have also been described as a possible point of entry for subsequent myocardial infection by Aspergillus [12]. Myocarditis occurs following seeding during fungemia [73]. Aspergillus mural endocardial or pericardial infection can occur in the setting of hyphal invasion from the rapture of myocardial abscesses by hematogenous seeding [8].

Diagnosis of myocardial infection by Aspergillus is a clinical challenge. Although extensive necrosis and infarction accompany Aspergillus myocardial infection, ECG findings may be absent of nonspecific [12,76]. Williams [76] found $15 \%$ of 39 patients with Aspergillus myocardial infection had ECG abnormalities consistent with ischemia or infarction. Aspergillus MC has been described in patients who died due to complications of arrhythmias and congestive heart failure [81]. Other pathological findings described in cardiac aspergillosis include lethal infarctions secondary to direct extension of myocardial abscesses into major cardiac vessels or by embolic seeding of coronary vessels with thrombus formation and invasion of myocardial tissue, and involvement of conduction system resulting in heart block and death $[82,83]$.

\section{Cryptococcus (Cryptococcosis)}

Cryptococcus is a saprophytic, basidiomycetous, dimorphic fungus (can turn into yeast cells or into dikaryotichyphae) [46]. Virtually all cases of cryptococcosis are due to Cryptococcus neoformans (C. neoformans) and its closely related species, Cryptococcus gattii. C. neoformans has a worldwide distribution since it occurs in soil and avian habitats. The main portal of entry in humans is inhalation of airborne organisms into the lungs [1]. C. neoformans was first identified in the 1950s as an opportunistic fungus pathogen causing disease in individuals using steroid $[39,84,85]$ or those with lymphoproliferative disorders [86]. Inhaled Cryptococcus disseminated through the respiratory tract to cause pulmonary infections, and subsequently, due to C. neoformans predilection for CNS, the life-threatening meningoencephalitis both in immunocompromised and immunocompetent patients. If C. neoformans infection of the CNS is not cured, it is $100 \%$ fatal [46]. Disseminated C. neoformans infection is also fatal with cardiac involvement.

Prior to 1981, cryptococcosis was rare, with less than 1,000 cases reported in the United States [87]. Since the late 1980s, substantial escalations in immunosuppressive infections particularly HIV/AIDS, together with modern immunosuppressive and invasive medical interventions correlated with a significant increase in the incidences of cryptococcosis. In support, Cryptococcus infections have been associated with patients with qualitative and quantitative defects in cellular immune functions, specifically in CD4+ lymphocytes [1]. Mortality rates in AIDS patients range from $15 \%$ to $20 \%$ in the United States and $55 \%$ to $70 \%$ in Latin America and Sub-Saharan Africa despite optimal treatment [88]. Cryptoccoccal infection has also been documented in $2.8 \%$ of patients who have undergone solid transplant with a mortality rate of $42 \%$ [89]. The most important virulence factors of $C$. neoformans are capsule production, melanin synthesis and the ability to grow at 37 degrees Centigrade [46,90].

Despite increased cases of cryptococcosis, reports of myocardial involvement is uncommon. The initial documentation of myocardial involvement was in 1956 [91]. Subsequent reports occurred in 1962 in 2 cancer patients, and in 1965 in one patient with C. neoformans MC who developed CM, congestive HF, heart block and death in the absence of CNS involvement [92]. Other cases of $C$. neoformans MC were reported in a patient with end-stage cirrhosis and on steroids [13] and in patients with advanced AIDS disease [93,94]. The mechanisms underlying Cryptoccoccal infection of the myocardium and the development of $\mathrm{CM}$ remains unclear. However, pathologic characteristics of infection include the presence of yeast cells diffusely infiltrating the myocardium with minimal acute or chronic inflammation with may be foci of cardiomyocyte necrosis. Whereas overt myocardial manifestations are infrequent in AIDS patients with MC [69,95], ECG abnormalities and congestive $\mathrm{HF}$ associated with fatal outcomes have been documented [96].

\section{Histoplasma (Histoplasmosis)}

Histoplasma capsulatum is a dimorphic fungus transmitted by the inhalation of spores. First described in 1906 [98], today, it is the most prevalent cause of fungal respiratory infection affecting approximately 500,000 individuals annually in the United States [99]. Infection occurs during daily activities in areas where the fungus is endemic or in the course of occupational and recreational activities that disrupt the soil or accumulated dirt in old buildings, on bridges and in caves where bats have roosted [100]. Prior to the 1980s, myocardial infection by Histoplasma was infrequent and mostly encountered in cancer patients [101-104]. Since then, several cases of Histoplasma MC have been identified during autopsy analysis in AIDS patients $[95,105,106]$. Today, severe histoplasmosis is more common in the setting of immunodeficiency, in particular, in patients with malignancy or AIDS [20,26,27,107]. Histoplasma is the third common cause of fungal MC after Candida 
and Aspergillus [68]. MC occurs by hematogenous dissemination [108-110]. Although its pathophysiology is not clear, pathological features may include Histoplasma granulomas containing numerous macrophages filled with yeast cells with substantial destruction of adjacent myocytes [109]. However, in AIDS patients, histocytes with intracellular yeast cells may be present between myocardial fibres with minimal inflammation in the absence of granuloma formation $[105,111]$. In most cases, clinical manifestation is asymptomatic with non-specific ECG changes and cardiomegaly [110].

\section{Blastomyces (Blastomycosis)}

Blastomyces dermatitidis is an endemic thermally dimorphic fungus that causes Blastomycosis, a disease that is predominant in North America. The fungus is ubiquitous, living in the environment particularly in moist soils and decomposing matter such as wood and leaves. The main portal of entry in humans is inhalation of airborne microscopic fungal spores often after participating in activities that disturb the soil [112]. Less commonly, Blastomyces may enter human host through direct cutaneous inoculation via a penetrating outdoor injury, a laboratory accident or even the bite of an infected dog [113]. Human immune system (phagocytic actions of alveolar macrophages in the lung) provide natural resistance to conidia of the Blastomyces inhibiting its transformation to the pathogenic yeast form. Proliferation of the yeast form in the alveoli (failure of the natural resistance to Blastomyces) leads to lymphohematogenous dissemination with foci of infection potentially spreading to any organ system including genitourinary, the CNS and less commonly the myocardium $[113,114]$.

Myocardial involvement in disseminated infection by Blastomyces is uncommon. The first case of disseminated infection of Blastomyces accompanied by myocardial involvement was in 1904 [115]. Since then, many several cases of myocardial infection due to hematogenous seeding have been reported [9,117]. Myocardial and endocardial infection can co-occur in disseminated infection by Blastomyces. Endocarditis secondary to direct extension from a pulmonary or mediastinal blastomycotic lesion have been described with associated myocardial abscesses $[9,117,118]$. Immunodeficient individuals are at increased risk of disseminated blastomycosis. Advanced HIV infection predisposes patients to severe blastomycosis and cases of disseminated blastomycosis with myocardial involvement have been described $[119,120]$. Characteristic pathological findings associated with Blastomyces infection include granulomas with central caseation surrounded by giant cells containing $B$. dermatitidis yeast cells $[117,121]$. Myocardial infection may be asymptomatic but impaired cardiac function has been described [117].

\section{Coccidioides (Coccidioidomycosis)}

Coccidioides is the oldest and the most virulent of the primary fungal pathogens in humans caused by two distinct species (Coccidioides immitis and Coccidioides posadasii). Presentation of disease, diagnosis and treatment do not appear to differ between the two species [122]. Coccidioides is dimorphic fungus with saprophytic and parasitic phases, and its infection causes coccidioidomycosis. It grows in soil as mycelia eventually bearing arthroconidia, the infectious propagule [123]. Humans acquire infection from the environment by inhalation of airborne arthroconidia from disturbed soil. In the laboratory cultures, Coccidioides grows as extremely infectious mycelial form, which may be hazardous to laboratory workers [124]. Inhaled conidia initiates a respiratory infection. In immunocompetent individuals, the infection is self-limiting but in immunocompromised individuals, pregnant women, solid-organ transplant patients, individuals of African descent, the infection can disseminate and cause life-threatening conditions. Of the deep mycoses, coccidioidomycosis is the least responsive to treatment [123]. Coccidioidomycosis can also occur in immunocompetent individuals but the disease is largely self-limiting [124].

Symptomatic disseminated Coccidioides infection beyond the lungs is uncommon, infecting less than $1 \%$ of primary pulmonary infection [122]. Dissemination is the result of fungemia occurring after the initial respiratory infection most commonly involving the skin, the bones or joints, and the CNS. Myocardial involvement is rare $[122,124]$. Autopsy studies indicate an incidence between $9 \%$ and $28 \%$ in patients with disseminated coccidioidomycosis and myocardial involvement $[51,125,126]$. Several cases of disseminated infection with spherules detected in the myocardium have been described [51,127]. Characteristic pathological findings in coccidioidomycosis include myocardial abscesses marked with central zones of necrosis containing spherules both inside and outside of multi-nucleated giant cells accompanied by a diffuse interstitial mononuclear cell infiltrate, and often organisms are absent in the inflammatory lesions [126]. Spherules have been isolated in the myocardium of AIDS patients suggesting they are at a high risk for hematogenous dissemination infection from $C$. immitis $[26,27,128,129]$. Coccidioidomycosis is an uncommon cause of fugal endocarditis with possible involvement of the mural endocardium and the underlying myocardium $[108,126]$. In coccidioidomycosis endocarditis, infection can occur due to hematogenous seeding of $C$. immitis [108]. Dyspnoea and non-specific ECG abnormalities have been reported in MC patients, which are also common in patients with primary pulmonary coccidioidomycosis $[125,126,130]$. Symptomatic co-occurring pericarditis may occur due to rupture of myocardial abscesses into the pericardial space $[125,126,131]$.

\section{Meta-analysis of diagnosis/management}

The aim of this systematic review and meta-analysis is to determine the prevalence, risk factors, diagnostic methods and treatment options for patients with FCM. A systematic online search for studies on the prevalence, diagnosis and management of FCM was performed on PubMed, EMBASE and Cochrane from inception to April 2019. To avoid overlooking studies that did not mention FCM in the title or abstract, the first 200 relevance-ranked articles retrieved with a full-text Google Scholar search were included. There was no restriction on publication time or language. Additional studies were retrieved from a manual review of the included studies and review articles. The search criteria included population of interest (patients with invasive fungal infection of the myocardium), diagnostic tests (histopathological, culture, microscopic, ECG and imaging) and clinical intervention methods (prophylactic and curative, pharmacological and non-pharmacological). Studies excluded included conference abstracts, case reports and review articles. In total, the online and manual search retrieved 325 articles. After a review of title, abstract and full-text, twenty-two (22) studies were included in this systematic review and meta-analysis $[13,52,58,130,132,149]$. The studies were published between 1955 [130] and 2017 [149], a period sufficiently large to provide valuable insights into the development of fungal infection and treatment overtime. Table 1 provides a summary of the main characteristics of the included studies.

\section{Findings}

Pooled-analysis: The 22 studies included in this systematise review and meta-analysis comprised of nine (41\%) autopsy studies $[13,52,58,132-136,143]$, seven $(32 \%)$ retrospective studies [138,144149], five (23\%) prospective studies $[130,137,139,141,142]$, and one 
Table 1: Characteristics of the included studies

\begin{tabular}{|c|c|c|c|c|c|c|c|}
\hline \begin{tabular}{|l|} 
First author \\
(year) [Ref \#]
\end{tabular} & Study design & $\begin{array}{l}\text { Patient type } \\
\text { (No.) }\end{array}$ & $\begin{array}{l}\text { Fungal } \\
\text { pathogens (No.) }\end{array}$ & $\begin{array}{l}\text { Diagnostic } \\
\text { methods }\end{array}$ & Risk factors & Treatment strategy & Summary of the main findings \\
\hline $\begin{array}{l}\text { Tudbury (1955) } \\
{[130]}\end{array}$ & Prospective & $\begin{array}{l}\text { Pulmonary } \\
\text { coccidiosis with } \\
\text { chest pain (20) }\end{array}$ & Coccidioides & ECG & NR & $\begin{array}{l}\text { Bed rest; } \\
\text { acetylsalicylic acid } \\
\text { for pain }\end{array}$ & $\begin{array}{l}\text { ECG may be useful in differentiating MI } \\
\& \text { pericarditis from pulmonary coccidiosis } \\
\text { with chest pains. }\end{array}$ \\
\hline $\begin{array}{l}\text { Blankenhorn } \\
(1956)[132]\end{array}$ & Autopsy & Myocarditis (77) & NR & $\begin{array}{l}\text { ECG (records); } \\
\text { microscopic; } \\
\text { histological }\end{array}$ & NR & NR & $\begin{array}{l}\text { ECG abnormalities are common in cardiac } \\
\text { infection by fungi }\end{array}$ \\
\hline Gruhn (1963) [52] & Autopsy & $\begin{array}{l}\text { Leukaemia/ } \\
\text { lymphoma (48) }\end{array}$ & $\begin{array}{l}\text { Candida (19); } \\
\text { Aspergillus (8); } \\
\text { Cryptococcus (2) }\end{array}$ & $\begin{array}{l}\text { histopathology; } \\
\text { fungal culture }\end{array}$ & $\begin{array}{l}\text { Type of Leukaemia } \\
\text { (granulocytic, } \\
\text { lymphocytic, } \\
\text { monocytic) }\end{array}$ & Chemotherapy & $\begin{array}{l}\text { Leukaemia imposes a greater risk than } \\
\text { lymphoma for invasive fungal infection. } \\
\text { Increase in Candida and Aspergillus } \\
\text { infection correlate with modern therapy }\end{array}$ \\
\hline Walsh (1980) [13] & Autopsy & $\begin{array}{l}\text { Cardiac fungal } \\
\text { infection }(50)\end{array}$ & $\begin{array}{l}\text { Candida (34); } \\
\text { Aspergillus (13); } \\
\text { Cryptococcus (3) }\end{array}$ & $\begin{array}{l}\text { Microscopic; } \\
\text { histopathology; } \\
\text { fungal culture }\end{array}$ & $\begin{array}{l}\text { Surgery (27); } \\
\text { Corticosteroids, } \\
\text { antineoplastic or } \\
\text { antibiotic (43) }\end{array}$ & $\begin{array}{l}\text { Corticosteroids; } \\
\text { antineoplastic; or } \\
\text { antibiotic }\end{array}$ & $\begin{array}{l}\text { Fungal MC may be difficult to diagnose } \\
\text { despite therapeutic interventions has an } \\
\text { ominous prognosis }\end{array}$ \\
\hline $\begin{array}{l}\text { Atkinson (1984) } \\
{[58]}\end{array}$ & Autopsy & $\begin{array}{l}\text { Cardiac fungal } \\
\text { infection }(60)\end{array}$ & $\begin{array}{l}\text { Candida (37); } \\
\text { Aspergillus (11); } \\
\text { Cryptococcus (2) }\end{array}$ & $\begin{array}{l}\text { Medical records, } \\
\text { histopathology; } \\
\text { microscopic }\end{array}$ & $\begin{array}{l}\text { Surgery (15); Neoplasm } \\
\text { (13); IV drug (2); GI } \\
\text { (5); immune disease (4) }\end{array}$ & $\begin{array}{l}\text { Antibiotics; } \\
\text { antineoplastic, } \\
\text { corticosteroids; } \\
\text { chemotherapy; } \\
\text { antifungal }\end{array}$ & $\begin{array}{l}\text { Patients with prior antineoplastic drugs, } \\
\text { antibiotics or corticosteroids have a higher } \\
\text { incidence of fungal myocarditis }\end{array}$ \\
\hline $\begin{array}{l}\text { Chinen (2007) } \\
{[133]}\end{array}$ & Autopsy & $\begin{array}{l}\text { Cardiac fungal } \\
\text { infection }(50)\end{array}$ & $\begin{array}{l}\text { Candida (36); } \\
\text { Aspergillus (9); } \\
\text { Cryptococcus (1) }\end{array}$ & $\begin{array}{l}\text { Medical records, } \\
\text { histopathology; } \\
\text { microscopic }\end{array}$ & $\begin{array}{l}\text { Neoplasm (23); } \\
\text { hematologic (10); renal } \\
\text { disease (7); liver disease } \\
\text { (5); DM (5) }\end{array}$ & $\begin{array}{l}\text { Antibiotics; } \\
\text { corticosteroids; } \\
\text { antineoplastic; } \\
\text { antifungal }\end{array}$ & $\begin{array}{l}\text { Increasing incidence of non-candidal } \\
\text { fungal infection over time, and a need to } \\
\text { define diagnostic \& therapeutic strategies } \\
\text { for non-candidal infection. }\end{array}$ \\
\hline $\begin{array}{l}\text { Larbcharoensub } \\
(2007)[134]\end{array}$ & Autopsy & $\begin{array}{l}\text { Invasive fungal } \\
\text { infection (155) }\end{array}$ & $\begin{array}{l}\text { Candida (80); } \\
\text { Aspergillus (88); } \\
\text { Cryptococcus (5); } \\
\text { Histoplasma (1) }\end{array}$ & $\begin{array}{l}\text { Medical records, } \\
\text { histopathology; } \\
\text { microscopic }\end{array}$ & $\begin{array}{l}\text { Hematologic } \\
\text { malignancies (48), } \\
\text { severe immune disease } \\
(1)\end{array}$ & Corticosteroids & $\begin{array}{l}\text { A diagnosis of invasive fungal infection } \\
\text { requires a high index of suspicion, } \\
\text { especially in immunocompromised } \\
\text { patients who presented with prolonged } \\
\text { fever. }\end{array}$ \\
\hline $\begin{array}{l}\text { Uppin }(2011) \\
{[135]}\end{array}$ & Autopsy & $\begin{array}{l}\text { Fungal infection } \\
{[35]}\end{array}$ & Aspergillus (18) & $\begin{array}{l}\text { Medical records, } \\
\text { histopathology; } \\
\text { fungal culture }\end{array}$ & $\begin{array}{l}\text { Leukaemia (7); steroids } \\
\text { (1); prolonged antibiotic } \\
\text { (3) }\end{array}$ & NR & $\begin{array}{l}\text { Existing diagnostic modalities are not } \\
\text { sensitive to ensure ante mortem diagnosis } \\
\text { of fungal infections }\end{array}$ \\
\hline $\begin{array}{l}\text { Lewis (2013) } \\
{[136]}\end{array}$ & Autopsy & $\begin{array}{l}\text { Haematological } \\
\text { malignancies } \\
(371)\end{array}$ & $\begin{array}{l}\text { Candida (31), } \\
\text { Aspergillus (23) }\end{array}$ & $\begin{array}{l}\text { Histopathology; } \\
\text { fungal culture }\end{array}$ & Leukaemia, lymphoma & $\begin{array}{l}\text { Corticosteroid, } \\
\text { chemotherapy }\end{array}$ & $\begin{array}{l}\text { IFIs remain a common infection in } \\
\text { haematological malignancies patients but } \\
\text { with decreasing prevalence }\end{array}$ \\
\hline $\begin{array}{l}\text { Gupta (2016) } \\
{[137]}\end{array}$ & Prospective & $\begin{array}{l}\text { ICU patients with } \\
\text { IFI (52) }\end{array}$ & $\begin{array}{l}\text { Candida (42), } \\
\text { Aspergillus (10) }\end{array}$ & Fungal culture & $\begin{array}{l}\text { Tracheostomy, parental } \\
\text { nutrition, central venous } \\
\text { line, urinary catheter, } \\
\text { mechanical ventilation, } \\
\text { prior antibiotic }\end{array}$ & NR & $\begin{array}{l}\text { Fungal infections have high mortality } \\
\text { rate; the importance of ICU surveillance } \\
\text { to document distribution, susceptibility } \\
\text { patterns and guide treatment }\end{array}$ \\
\hline Shen (2007) [138] & Retrospective & $\begin{array}{l}\text { IFI in AIDS } \\
\text { patients (35) }\end{array}$ & $\begin{array}{l}\text { Candida (31); } \\
\text { Cryptococcus } \\
(10)\end{array}$ & Fungal culture & $\begin{array}{l}\text { CD4 }{ }^{+} \text {T-lymphocyte } \\
\text { counts }<100 \text { cells } \mathrm{mm}^{-3}\end{array}$ & $\begin{array}{l}\text { Antiretroviral; } \\
\text { antifungal therapy }\end{array}$ & $\begin{array}{l}\text { IFI is a common opportunistic infection in } \\
\text { AIDS patients with low CD } 4+\text { count with } \\
\text { Candida being the most prominent }\end{array}$ \\
\hline $\begin{array}{l}\text { Wadhwa (2007) } \\
{[139]}\end{array}$ & Prospective & $\begin{array}{l}\text { Symptomatic } \\
\text { AIDS-related } \\
\text { opportunistic } \\
\text { mycoses (60) }\end{array}$ & $\begin{array}{l}\text { Candida (16); } \\
\text { Aspergillus (5); } \\
\text { Cryptococcus (7); } \\
\text { Histoplasma (2) }\end{array}$ & $\begin{array}{l}\text { Medical history; } \\
\text { fungal culture }\end{array}$ & Low CD4 count & NR & $\begin{array}{l}\text { Various fungal infections correlated well } \\
\text { with the mean CD4 counts. }\end{array}$ \\
\hline $\begin{array}{l}\text { Badiee (2009) } \\
{[140]}\end{array}$ & Cross-sectional & $\begin{array}{l}\text { Immuno- } \\
\text { compromised } \\
\text { patients with IFI } \\
(310)\end{array}$ & $\begin{array}{l}\text { Candida (178); } \\
\text { Aspergillus (19); }\end{array}$ & Fungal culture & Solid organ transplant & $\begin{array}{l}\text { Chemotherapy, } \\
\text { antibiotic, antifungal } \\
\text { therapy }\end{array}$ & $\begin{array}{l}\text { Immunocompromised patients should } \\
\text { be checked weekly by molecular assays } \\
\text { early diagnosis or exclusion of fungal } \\
\text { infections. }\end{array}$ \\
\hline Kaur (2016) [141] & Prospective & $\begin{array}{l}\text { AIDs patients } \\
\text { with fungal } \\
\text { infection }(280)\end{array}$ & $\begin{array}{l}\text { Candida (141); } \\
\text { Aspergillus (5); } \\
\text { Cryptococcus (5) }\end{array}$ & Fungal culture & Low CD4 count & NR & $\begin{array}{l}\text { Candidiasis is a common infection in HIV/ } \\
\text { AIDS patients and clinician awareness } \\
\text { is important for early diagnosis and } \\
\text { treatment. }\end{array}$ \\
\hline $\begin{array}{l}\text { Viscoli (1999) } \\
{[142]}\end{array}$ & Prospective & $\begin{array}{l}\text { Cancer patients } \\
\text { with IFI (245) }\end{array}$ & Candida (121) & Fungal culture & $\begin{array}{l}\text { Bone marrow } \\
\text { transplant, antifungal } \\
\text { and antibiotic therapy, } \\
\text { septic shock }\end{array}$ & $\begin{array}{l}\text { Antifungal; } \\
\text { antibiotic }\end{array}$ & $\begin{array}{l}\text { Risk of candidemia in cancer patients } \\
\text { increases with allogeneic bone marrow } \\
\text { transplantation, septic shock, and lack of } \\
\text { antifungal prophylaxis }\end{array}$ \\
\hline $\begin{array}{l}\text { Chamilos (2006) } \\
{[143]}\end{array}$ & Autopsy & $\begin{array}{l}\text { IFI in hematologic } \\
\text { malignancies } \\
\text { patients (179) }\end{array}$ & $\begin{array}{l}\text { Candida (28); } \\
\text { Aspergillus (17) }\end{array}$ & $\begin{array}{l}\text { Medical records; } \\
\text { histopathology }\end{array}$ & GvHD; neutropenia & NR & $\begin{array}{l}\text { Current diagnostic methods so not capture } \\
\text { well the epidemiology of IFI in severely } \\
\text { immunocompromised patients. The } \\
\text { prevalence of mold infection is increasing }\end{array}$ \\
\hline $\begin{array}{l}\text { Pagano (2006) } \\
{[144]}\end{array}$ & Retrospective & $\begin{array}{l}\text { IFI in hematologic } \\
\text { malignancies } \\
\text { patients }(538)\end{array}$ & $\begin{array}{l}\text { Candida (175); } \\
\text { Aspergillus (310); } \\
\text { Cryptococcus (8) }\end{array}$ & $\begin{array}{l}\text { Medical records } \\
\text { review }\end{array}$ & $\begin{array}{l}\text { Types of hematologic } \\
\text { malignancies }\end{array}$ & $\begin{array}{l}\text { Chemotherapy; } \\
\text { antifungal }\end{array}$ & $\begin{array}{l}\text { Hematologic malignancies predispose } \\
\text { patients to IFI particularly Aspergillus and } \\
\text { Candida with a high rate of morbidity and } \\
\text { mortality }\end{array}$ \\
\hline $\begin{array}{l}\text { Degregorio (1982) } \\
{[145]}\end{array}$ & Retrospective & $\begin{array}{l}\text { Leukemia on } \\
\text { chemotherapy } \\
(32)\end{array}$ & $\begin{array}{l}\text { Candida (24); } \\
\text { Aspergillus (14); } \\
\text { Cryptococcus (1) }\end{array}$ & $\begin{array}{l}\text { Medical records } \\
\text { review }\end{array}$ & $\begin{array}{l}\text { Severe neutropenia, } \\
\text { refractory to antibiotics }\end{array}$ & $\begin{array}{l}\text { Chemotherapy; } \\
\text { antifungal }\end{array}$ & $\begin{array}{l}\text { Leukaemia patients on chemotherapy are } \\
\text { at risk of invasive Candida and Aspergillus } \\
\text { infection with multiple organ involvement }\end{array}$ \\
\hline
\end{tabular}




\begin{tabular}{|l|l|l|l|l|l|l|l|}
\hline $\begin{array}{l}\text { First author } \\
\text { (year) [Ref \#] }\end{array}$ & Study design & $\begin{array}{l}\text { Patient type } \\
\text { (No.) }\end{array}$ & $\begin{array}{l}\text { Fungal } \\
\text { pathogens (No.) }\end{array}$ & $\begin{array}{l}\text { Diagnostic } \\
\text { methods }\end{array}$ & Risk factors & Treatment strategy & Summary of the main findings \\
\hline $\begin{array}{l}\text { Martino (2002) } \\
{[146]}\end{array}$ & Retrospective & $\begin{array}{l}\text { Allogeneic } \\
\text { PBSCT recipients } \\
\text { (46) }\end{array}$ & $\begin{array}{l}\text { Candida (12); } \\
\text { Aspergillus (32) }\end{array}$ & $\begin{array}{l}\text { Medical records } \\
\text { review }\end{array}$ & $\begin{array}{l}\text { Steroid prophylaxis; } \\
\text { post-transplant GvHD }\end{array}$ & $\begin{array}{l}\text { Antifungal; steroid } \\
\text { prophylaxis }\end{array}$ & $\begin{array}{l}\text { Aspergillosis is common after PBSCT } \\
\text { with increased risk with the use of steroid } \\
\text { prophylaxis and GVHD }\end{array}$ \\
\hline $\begin{array}{l}\text { Harrison (2015) } \\
{[147]}\end{array}$ & Retrospective & $\begin{array}{l}\text { Allogeneic HSCT } \\
\text { recipients (28) }\end{array}$ & $\begin{array}{l}\text { Candida (7); } \\
\text { Aspergillus (18) }\end{array}$ & $\begin{array}{l}\text { Medical records } \\
\text { review }\end{array}$ & $\begin{array}{l}\text { Intensive, immuno- } \\
\text { suppressive } \\
\text { therapy; GvHD; } \\
\text { transplant associated } \\
\text { microangiopathy }\end{array}$ & $\begin{array}{l}\text { Antifungal } \\
\text { prophylaxis, } \\
\text { immune-therapy }\end{array}$ & $\begin{array}{l}\text { Intensified immunosuppressive therapy } \\
\text { and transplant associated microangiopathy } \\
\text { are significant risk factors for IFDs in } \\
\text { HSCT patients }\end{array}$ \\
\hline Shi (2015) [148] & Retrospective & $\begin{array}{l}\text { Allogeneic HSCT } \\
\text { recipients (92) }\end{array}$ & $\begin{array}{l}\text { Candida (50); } \\
\text { Aspergillus (32) }\end{array}$ & $\begin{array}{l}\text { Medical records } \\
\text { review }\end{array}$ & $\begin{array}{l}\text { HLA mismatch; } \\
\text { neutropenia; GvHD; } \\
\text { corticosteroid, } \\
\text { cytomegalovirus }\end{array}$ & $\begin{array}{l}\text { Corticosteroid; } \\
\text { antifungal } \\
\text { prophylaxis }\end{array}$ & $\begin{array}{l}\text { Prior history of IFI, HLA mismatch, } \\
\text { neutropenia, and acute GVHD and } \\
\text { corticosteroid therapy are risk factors. }\end{array}$ \\
\hline Patel (2017) [149] & Retrospective & $\begin{array}{l}\text { Renal transplant } \\
\text { recipients (30) }\end{array}$ & $\begin{array}{l}\text { Candida (16); } \\
\text { Aspergillus (11) }\end{array}$ & $\begin{array}{l}\text { Presentation, } \\
\text { radiological, } \\
\text { histological }\end{array}$ & $\begin{array}{l}\text { Triple immune- } \\
\text { suppression, prolonged } \\
\text { antibiotics > 2 weeks, } \\
\text { and diabetes }\end{array}$ & $\begin{array}{l}\text { Immuno- } \\
\text { suppression, } \\
\text { antifungal } \\
\text { prophylaxis }\end{array}$ & $\begin{array}{l}\text { IFI is rare in renal transplant but } \\
\text { associated with increased morbidity and } \\
\text { mortality. }\end{array}$ \\
\hline
\end{tabular}

CMV: Cytomegalovirus; GvHD: Graft-versus-Host Disease; HLA: Human Leukocyte Antigen; HSCT: Hematopoietic Stem Cell Transplantation; IFI: Invasive Fungal Infection; PBSCT: Peripheral Blood Stem Cell Transplantation

(4\%) cross-sectional study [140]. In total, 2,793 patients with confirmed fungal myocardial infection accompanied by signs and/or symptoms of cardiac dysfunction were included. The patients were relatively young (mean age $=41.5$; range $=29$ to 51 years) and predominantly male (93.5\%). Individual studies included different patient populations with potential immunodeficiency. Cancer patients $(50.6 \% ; \mathrm{n}=1,413)$ in six studies [52,136,142-145]; AIDS patients $(24.5 \% ; \mathrm{n}=685)$ in four studies [138-141]; CFI patients $(12.5 \%$; $\mathrm{n}=350)$ in five studies $[13,58,133$ 135]; graft recipients $(7.0 \% ; \mathrm{n}=196)$ in four studies [146-149]; and in one study each, MC patients $(2.8 \% ; \mathrm{n}=77)$ [132]; ICU patients $(1.9 \%$; $\mathrm{n}=52)$ [137]; and pulmonary Coccidiosis with chest pains $(0.7 \% ; \mathrm{n}=20)$ [130]. The prevalence of myocardial fungal infection is relatively low. A pooled analysis of eleven (11) studies [52,132,135-138,144,146-149] that reported fungal infection of the myocardium in patients with disseminated fungal disease, and in immunocompromised patients (cancer, AIDS and graft recipients) indicated a prevalence of $11.9 \%$ (95\% CI: $6.0 \%$ to $22.2 \%$ ).

Although many fungal pathogens can infect the myocardium and cause cardiomyopathy, only three species have been extensively mentioned: Candida, Aspergillus and Cryptococcus. Of the three, Candida is the most dominant fungus pathogen infection the myocardium in the setting of disseminated infection. In a pooled analysis of 19 studies [13,52,58,133,134,136-149], Candida myocardial infection was found in 1,078 out of 2,661 patients translating into $47.8 \%$ of all the reported cases (95\% CI: $38.1 \%$ to $57.6 \%$ ) (Figure 1). The second most common fungus pathogen reported in 18 studies $[13,52,58,133-137,139-141,143-149]$ is Aspergillus, affecting 643 out of 2,416 patients translating into $24.4 \%$ (95\% CI: $14.7 \%$ to $37.6 \%$ ) of all the reported cases (Figure 2). Cases of Cryptococcus reported in 10 studies [13,52,58,133,134,138,139,141,144,145] was found in 44 out of 1,308 patients translating into $4.5 \%$ (95\% CI: $2.0 \%$ to $9.6 \%$ ) (Figure 3 ). Histoplasma infection was rare, reported only in two studies [134,139] infecting 3 out of 125 patients, about 1.9\% (95\% CI: $0.6 \%$ to $5.8 \%$ ). Cases of Blastomyces infections were extremely rare, mentioned only in passing in two studies categorized as other fungus infection $[58,148]$. In general, myocardial infection by a fungus pathogen has an ominous prognosis, with pooled data from six studies $[52,140,142,144,146,148]$ indicating 242 out of 1,279 deaths or a mortality rate of $30.9 \%$ (95\% CI: $20.8 \%$ to $43.2 \%$; $\mathrm{p}=0.003$ ).

Systematic review: The most dominant risk factor for cardiac fungal infection are diseases that disrupt the immune function. Cancer is the most common disease that has long been associated with cardiac fungal infection: neoplasm and hematologic malignancies $[52,58,133,134,136,144]$ ad well as the type of hematologic malignancies $[52,136,144]$. Advanced HIV or AIDS is another important risk factor for cardiac fungal infection since the mid-1980s especially in individuals with low CD4+ T-lymphocyte counts $(<100$ cells mm-3) [138-141]. Corticosteroids, antineoplastic or antibiotic are also important risk factors $[13,142,148]$. Surgery, including cardiac surgery and solid organ transplant (graft recipient, and bone marrow and renal transplant) are also significant risk factors $[140,142,148,149]$. In addition to these general risk factors, ICU patients are at an increased risk of fungal infection due to tracheostomy, parental nutrition, central venous line, urinary catheter, mechanical ventilation, and prior antibiotic use [137]. Additional risk factors for graft recipients include GvHD, HLA mismatch, severe neutropenia, transplant-associated microangiopathy, cytomegalovirus, corticosteroid therapy, prolonged antibiotic use, and immunosuppression therapy [143,146-149].

Diagnosis of cardiac fungal infection remains a clinical challenge. Degregorio et al. [145] reports only 9 out of 32 patients ( 28\%) with acute leukaemia had confirmatory diagnosis ante mortem. Usually diagnosis confirmed post-mortem (autopsy or histopathological analysis). A review of medical records and fungal culture or microscopic analysis are common ante mortem diagnostic methods [137-142, 144-148]. Although ECG abnormalities may be common, they are non-specific - inverted T-waves and low QRS voltage [130], and nonspecific myocardial changes, bundle branch block and atrioventricular heart block [132]. Non-invasive imaging using either echocardiography or cardiac magnetic resonance imaging have not been evaluated in patients with FCM or cardiac fungal infection. Although treatment using antifungal therapy is advised in patients with cardiac fungal infection [138,140,144,145,148], their therapeutic efficacy has not been demonstrated in randomized clinical trials, and their value in FCM patients remains unknown. Treatment for underlying diseases (cancer, graft recipients, AIDS) such as chemotherapy, antiretroviral and immunosuppression therapy are known risk factors for cardiac fungal infection and should be used cautiously.

\section{Discussion}

The present meta-analysis and systematic review purposed to evaluate diagnostic and clinical management methods for FCM. However, the search for studies revealed FCM is a grossly underresearched aetiology of $\mathrm{CM}$ relative to viral, bacterial and parasitic aetiologies. The revelation is consistent with Head et al. [5] findings 
Event Rate and $95 \% \mathrm{Cl}$ for Candida

\begin{tabular}{|c|c|c|c|c|c|c|c|c|c|}
\hline \multirow[t]{2}{*}{$\underline{\text { Study name }}$} & \multirow[b]{2}{*}{ Total } & \multicolumn{4}{|c|}{ Statistics for each study } & & \multicolumn{2}{|c|}{ Event rate and $95 \% \mathrm{Cl}$} & \\
\hline & & $\begin{array}{c}\text { Event } \\
\text { rate }\end{array}$ & $\begin{array}{l}\text { Lower } \\
\text { limit }\end{array}$ & $\begin{array}{l}\text { Upper } \\
\text { limit }\end{array}$ & p-Value & & & & \\
\hline Gruhn [52] & $19 / 48$ & 0.396 & 0.269 & 0.539 & 0.152 & 1 & & & I \\
\hline Walsh [13] & $34 / 50$ & 0.680 & 0.540 & 0.794 & 0.013 & & & & \\
\hline Atkinson [58] & $37 / 60$ & 0.617 & 0.489 & 0.730 & 0.073 & & & & \\
\hline Chinen [133] & $36 / 50$ & 0.720 & 0.581 & 0.827 & 0.003 & & & & \\
\hline Larbcharoensub [134] & $80 / 155$ & 0.516 & 0.438 & 0.594 & 0.688 & & & & \\
\hline Lewis [136] & $31 / 371$ & 0.084 & 0.059 & 0.116 & 0.000 & & & & \\
\hline Gupta [137] & $42 / 52$ & 0.808 & 0.678 & 0.893 & 0.000 & & & & \\
\hline Shen [138] & $31 / 35$ & 0.886 & 0.732 & 0.956 & 0.000 & & & & \\
\hline Wadhwa [139] & $16 / 60$ & 0.267 & 0.170 & 0.392 & 0.001 & & & & \\
\hline Badiee [140] & $178 / 310$ & 0.574 & 0.518 & 0.628 & 0.009 & & & & \\
\hline Kaur [141] & $141 / 280$ & 0.504 & 0.445 & 0.562 & 0.905 & & & & \\
\hline Viscoli [142] & $121 / 245$ & 0.494 & 0.432 & 0.556 & 0.848 & & & & \\
\hline Chamilos [143] & $28 / 179$ & 0.156 & 0.110 & 0.217 & 0.000 & & & & \\
\hline Pagano [144] & $175 / 538$ & 0.325 & 0.287 & 0.366 & 0.000 & & & & \\
\hline Degregorio [145] & $24 / 32$ & 0.750 & 0.574 & 0.870 & 0.007 & & & & \\
\hline Martino [146] & $12 / 46$ & 0.261 & 0.155 & 0.405 & 0.002 & & & & \\
\hline Harrison [147] & $7 / 28$ & 0.250 & 0.124 & 0.439 & 0.012 & & & & \\
\hline Shi [148] & $50 / 92$ & 0.543 & 0.441 & 0.642 & 0.405 & & & & \\
\hline \multirow[t]{3}{*}{ Patel [149] } & $16 / 30$ & 0.533 & 0.358 & 0.701 & 0.715 & & & & \\
\hline & $1078 / 2661$ & 0.478 & 0.381 & 0.576 & 0.659 & & & & \\
\hline & & & & & & -1.00 & -0.50 & 0.00 & 1.00 \\
\hline
\end{tabular}

Test for Heterogeinity: ${ }^{\wedge}{ }^{\wedge}=\mathbf{9 4 . 8 3 \%} ; \mathrm{p}=\mathbf{0 . 0 0 0}$

Figure 1: Forest plot for event rate of candida infection

Event Rate and $95 \% \mathrm{Cl}$ for Aspergillus

\begin{tabular}{|c|c|c|c|c|c|c|c|c|c|}
\hline \multirow[t]{2}{*}{ Study name } & \multicolumn{5}{|c|}{ Statistics for each study } & & \multicolumn{2}{|c|}{ Event rate and $95 \% \mathrm{Cl}$} & \\
\hline & Total & $\begin{array}{l}\text { Event } \\
\text { rate }\end{array}$ & $\begin{array}{c}\text { Lower } \\
\text { limit }\end{array}$ & $\begin{array}{c}\text { Upper } \\
\text { limit }\end{array}$ & p-Value & & & & \\
\hline Gruhn [52] & $8 / 48$ & 0.167 & 0.086 & 0.299 & 0.000 & & & & \\
\hline Walsh [13] & $13 / 50$ & 0.260 & 0.157 & 0.398 & 0.001 & & & & \\
\hline Atkinson [58] & $11 / 60$ & 0.183 & 0.105 & 0.302 & 0.000 & & & & \\
\hline Chinen [133] & $9 / 50$ & 0.180 & 0.096 & 0.311 & 0.000 & & & & \\
\hline Larbcharoensub [134] & $88 / 155$ & 0.568 & 0.489 & 0.643 & 0.093 & & & & \\
\hline Uppin [135] & $18 / 35$ & 0.514 & 0.353 & 0.673 & 0.866 & & & & \\
\hline Lewis [136] & $23 / 371$ & 0.062 & 0.042 & 0.092 & 0.000 & & & & \\
\hline Gupta [137] & $10 / 52$ & 0.192 & 0.107 & 0.322 & 0.000 & & & & \\
\hline Wadhwa [139] & $5 / 60$ & 0.083 & 0.035 & 0.185 & 0.000 & & & & \\
\hline Badiee [140] & $19 / 310$ & 0.061 & 0.039 & 0.094 & 0.000 & & & & \\
\hline Kaur [141] & $5 / 280$ & 0.018 & 0.007 & 0.042 & 0.000 & & & & \\
\hline Chamilos [143] & $17 / 179$ & 0.095 & 0.060 & 0.147 & 0.000 & & & & \\
\hline Pagano [144] & $310 / 538$ & 0.576 & 0.534 & 0.617 & 0.000 & & & & \\
\hline Degregorio [145] & $14 / 32$ & 0.438 & 0.279 & 0.610 & 0.481 & & & & \\
\hline Martino [146] & $32 / 46$ & 0.696 & 0.549 & 0.811 & 0.010 & & & & \\
\hline Harrison [147] & $18 / 28$ & 0.643 & 0.454 & 0.796 & 0.136 & & & & \\
\hline Shi [148] & $32 / 92$ & 0.348 & 0.258 & 0.450 & 0.004 & & & & \\
\hline \multirow[t]{3}{*}{ Patel [149] } & $11 / 30$ & 0.367 & 0.216 & 0.549 & 0.149 & & & & \\
\hline & $643 / 2416$ & 0.244 & 0.147 & 0.376 & 0.000 & & & & \\
\hline & & & & & & -1.00 & -0.50 & 0.00 & 1.00 \\
\hline
\end{tabular}

Test for Heterogeinity: $\left.\right|^{\wedge} 2=94.83 \% ; p=0.000$

Figure 2: Forest plot for event rate of aspergillus infection 


\section{Event Rate and $95 \% \mathrm{Cl}$ for Cryptococcus}

\begin{tabular}{|c|c|c|c|c|c|c|c|c|c|}
\hline \multirow[t]{2}{*}{ Study name } & \multirow[b]{2}{*}{ Total } & \multicolumn{4}{|c|}{ Statistics for each study } & & \multicolumn{2}{|c|}{ Event rate and $95 \% \mathrm{Cl}$} & \\
\hline & & $\begin{array}{c}\text { Event } \\
\text { rate }\end{array}$ & $\begin{array}{c}\text { Lower } \\
\text { limit }\end{array}$ & $\begin{array}{c}\text { Upper } \\
\text { limit }\end{array}$ & p-Value & & & & \\
\hline Gruhn [52] & $2 / 48$ & 0.042 & 0.010 & 0.152 & 0.000 & & & & \\
\hline Walsh [13] & $3 / 50$ & 0.060 & 0.019 & 0.170 & 0.000 & & & & \\
\hline Atkinson [58] & $2 / 60$ & 0.033 & 0.008 & 0.124 & 0.000 & & & & \\
\hline Chinen [133] & $1 / 50$ & 0.020 & 0.003 & 0.129 & 0.000 & & & & \\
\hline Larbcharoensub [134] & $5 / 155$ & 0.032 & 0.013 & 0.075 & 0.000 & & & & \\
\hline Shen [138] & $10 / 35$ & 0.286 & 0.161 & 0.454 & 0.014 & & & & \\
\hline Wadhwa [139] & $7 / 60$ & 0.117 & 0.057 & 0.225 & 0.000 & & & & \\
\hline Kaur [141] & $5 / 280$ & 0.018 & 0.007 & 0.042 & 0.000 & & & & \\
\hline Pagano [144] & $8 / 538$ & 0.015 & 0.007 & 0.029 & 0.000 & & & & \\
\hline \multirow[t]{3}{*}{ Degregorio [145] } & $1 / 32$ & 0.031 & 0.004 & 0.191 & 0.001 & & & & \\
\hline & $44 / 1308$ & 0.045 & 0.020 & 0.096 & 0.000 & & & & \\
\hline & & & & & & -0.50 & -0.25 & 0.00 & 0.50 \\
\hline
\end{tabular}

Test for Heterogeinity: $I^{\wedge} 2=83.66 \% ; p=0.000$

Figure 3: Forest plot for event rate of cryptococcus infection

that fungal infection is the least funded infectious disease research in the UK. Furthermore, research on immunology and infectious diseases by Welcome Trust (U.K charitable organization), the U.K. Medical Research Council and the U.S. National Institutes of Health allocated only $1.4 \%$ to $2.5 \%$ to medical mycology [1]. Despite a paucity of studies, data from patients with cardiac fungal infection with signs and/ or symptoms of cardiac dysfunction assisted in providing a valuable insight into the major fungal pathogens causing FCM, risk factors, diagnosis and treatment. The present meta-analysis finds FCM affects $\sim 12 \%$ of immunocompromised patients with disseminated fungal infection. The three most prevalent fungal pathogens responsible for FCM are Candida (47\%), Aspergillus (24\%), and Cryptococcus (5\%). Other fungus species such as Histoplasma and Blastomyces are extremely rare aetiologies of FCM, usually mentioned as other causes in a majority of studies. Cardiac fungal infection is potentially lethal, with a mortality rate of $\sim 31 \%$, which should encourage research interests into disseminated fungal infection with cardiac involvement.

\section{Prevalence}

The incidence of cardiac fungal infection has been rare up until the 1960s [8]. In the present meta-analysis, the incidence of $12 \%$ is due primarily to a rise in immunocompromised patients, and secondarily due to modern treatment. The low incidence of cryptococcosis, histoplasmosis coccidioidomycosis and blastomycosis suggests they are not causally correlated with modern therapy. In contrast, the marked increased in the incidence of candidiasis and aspergillosis appears to be causally associated with modern therapy and the increase in immunocompromised patients. The correlation between increasing fungal infection and the rise in immunodeficient patients is consistent with current literature on medical mycoses. Fungi are opportunistic pathogens that exploit defects in the immune system and cause diseases in many sites and settings [150]. General risk factors for invasive fungal infection are exposure to pathogens and an immunologically impaired host such as patients infected with HIV, those taking chronic systemic steroids or transplant recipients. Contaminated devices such intravenous drug use, catheters, prostheses are other potential clinical sources of invasive fungal infection [150].
Candida continues to be the most frequent cause of cardiac fungal infection, mainly in transplant recipient patients (implanted with foreign bodies). Candida creates a protective barrier over their colonies as they are established. The exopolymeric nature of the biofilm limits the access of antifungal agents to the pathogens, decreasing the possibility of a cure when the foreign body still resides within the patient. The filtering effect of the biofilm, varying fungal colony growth rate and the ability to excrete antifungal from the colony within the film could be key factors in the persistent Candidal infection despite adequate antifungal levels [151]. Although Candida is the most frequent cause of invasive fungal infections in most patients populations, prophylaxis and widespread use of antifungal drugs as empiric therapy for neutropenic fever is influencing a shift in the epidemiology of Candidal infection. Infection by Candida species other than C. albicans - C. glabrata, C. parapsilosis, C. tropicalis, C. krusei, and C. lusitaniae are becoming more prevalent relative to $C$. albicans [152].

Aspergillus is the second most common fungal pathogen causing invasive fungal disease. Its prevalence may be increasing relative to Candida in some patient population. The efficacy of antifungal prophylaxis (fluconazole) in preventing Candida infection has been proven more than two decades ago [157] and thus the shifting epidemiology often requires using regimens that also cover Aspergillus [143]. Already in graft recipients - HLA-identical sibling PBSCT - nonCandida invasive fungi infection especially Aspergillus infection has a higher number of cases: 32 versus 12 in 395 PBSCT patients [146] and 18 versus 7 in 242 HSCT patients [147]. The risk factors for increased cases of Aspergillus infection in PBSCT include the use of steroid prophylaxis, the development of moderate to severe GvHD post -transplant [146], and in HSCT, patients included intense immunosuppressive therapy because of severe GvHD, transplant-associated microangiopathy while antifungal given during aplasia and post-engraftment associated with reduced risk [147]. In immunocompromised patients, increased cases of secondary candidiasis and aspergillosis may be attributed to damaged reticuloendothelial system due to leukaemia or aggravated by the use of cytotoxic drugs; alterations in the normal gastrointestinal and pulmonary microbiological flora by antibiotic therapy; and depression of tissue resistance by steroids [52]. While Candida and Aspergillus have 
received a disproportionate research focus, there is need for studies on other fungal pathogens - Cryptococcus, Histoplasma, Blastomyces and Coccidioides - including their pathophysiology in cardiac infection, diagnosis and management.

Diagnosis: Confirmatory ante mortem diagnosis of invasive fungal infection of the heart is difficult with a greater proportion confirmed post-mortem. This may explain why a majority of the studies in this meta-analysis (41\%) were autopsy analysis or diagnosis was confirmed by histopathological analysis $[13,52,58,132$ $136,143]$. In the reviewed data, a significant proportion of patients with disseminated fungal disease $(\sim 12 \%)$ will develop myocardial infection. Establishing a definite diagnosis of invasive fungal infection of the myocardium in immunocompromised patients remains both challenging and time consuming but delayed initiation of antifungal treatment increases mortality. This has led to the strategy of initiating either empirical or pre-emptive antifungal therapy prior to the final diagnosis. However, emerging diagnostic procedures such as newer imaging techniques and non-culture methods, including antigenbased assays, metabolite detection and molecular detection of fungal DNA from body fluid samples may improve diagnosis. The revised 2012 IFI haematology and oncology guidelines by the Infectious Diseases Working Party of the German Society of Haematology and Oncology (AGIHO) recommends a combination of microscopy, mycological culture, antigen and antibody detection, molecular diagnostics, and non-invasive imaging [154]. However, current recommendations for diagnostic of IFI in cancer patients by the US Mycoses Study Group (MSG) and the Infectious Disease Group of the European Organization for Research and Treatment of Cancer (EORTC) [155] were developed more for use in clinical trials than in bedside decision-making [156].

Routine microbiological testing such as microscopy and mycological culture often fails to identify the infecting fungal pathogens [8]. Routine antigen and antibody detection is sometimes not recommended for Candida while routine Aspergillus antibodies may not recommended in patients with haemato-oncological malignancies. Molecular diagnostics methods such as PCR for detecting DNA from clinical specimen such as Aspergillus PCR are promising and display a high sensitivity and specificity Graded as A: good evidence to support recommendation by the AGIHO. However, since fungal PCR is neither standardized nor a widely available diagnostic tool, it is yet to be included as mandatory in the diagnostic guidelines. Thus, may be used in combination with other non-cultural tests such as antigen detection [154]. Myocardial involvement in fungal infection is often clinically silent. Clinical symptoms of dyspnoea may be attributable to concomitant pulmonary infection. Generally, ECG findings are not very helpful in detecting myocardial fungal infection $[54,59,60]$. Similarly, endomyocardial biopsy is insensitive in the diagnosis of cardiac involvement after fungal infection [157,158]. However, if a patient exhibits inflammatory response in cardiac tissues, analysis of the infiltrating cell type in the myocardium may be helpful. In majority of cases of infectiosum MC, T-lymphocytes and macrophages predominate while neutrophils are more common in fungal MC [157]. Echocardiography imaging particularly transesophageal echocardiography has had some success in detecting fungal MC in the presence of endocardial abnormalities $[159,162]$. Cardiac magnetic resonance (CMR) imaging particularly spin echo has been promising in detecting the presence of MC. CMR imaging may be useful in detecting MC in the setting of disseminated fungal disease with signs and/or symptoms of cardiac dysfunction $[163,164]$.
Treatment: In the reviewed data, antifungal treatment is the mainstay of treatment of invasive fungal infection particularly in immunocompromised patients. Amphotericin B, fluconazole and itraconazole are the cornerstone of the treatment of invasive fungal infections [165]. In the present review, increased risk of fungal infection, it is a common standard clinical practice to administer empirical or pre-emptive antifungal therapy in febrile immunodeficient patients unresponsive to antibiotic therapy [166-169]. Current standard clinical practice recommends that all cases of disseminated Candida infection should be treated because of the potential of Candida to cause metastatic disease [170]. In oncology patients, primary antifungal prophylaxis is standard in the management of immunosuppressed oncology patients [170]. Antifungal prophylaxis for Candida decreases the incidence of serious candidiasis in premature infants and in AIDS patients [171174]. Liposomal amphotericin, with its reduced nephrotoxicity and infusion-related infections, improved the ability to treat patients with invasive fungal disease [165].

Voriconazole and caspofungin are recent addition to the medications licensed for the treatment of invasive fungal infections. Voriconazole has a broad spectrum and activity and is available both orally and parenterally, and may be suitable as a second-line therapy in selected patients, particular those with fungal infection that is non-responsive to first-line treatment. However, there is no evidence showing superiority of Voriconazole to either amphotericin $\mathrm{B}$ or itraconazole in the treatment of invasive Candida or Aspergillus infection. Caspofungin on the other hand is available intravenously only and appears to be better tolerated than amphotericin B. It inhibits the synthesis of the 1,3-betaD-glucan component of the cell wall in diverse pathogenic fungi, may increase the ability to treat fungal infections Presently, Caspofungin is used as a second-line treatment in patients with life-threatening invasive Candida or Aspergillus infection that is unresponsive to first-lien therapy [165]. More effective treatment regimens and more rapid institution of antifungal therapy is important to reduce the incidence and outcomes of disseminated fungal disease [8].

\section{Implications}

The reviewed data reveals FCM is an uncommon myocardial complication of disseminated fungal infection and a rare aetiology of infectious cardiomyopathy, and its impact on human health, grossly under-researched. The bulk of the current evidence on cardiac fungal infection comes from early autopsy studies published in the last half of the $20^{\text {th }}$ Century, which have not capture the changing epidemiology of fungal infection and advancements made in medical technology including surgical, prophylactic and therapeutic interventions. Moreover, a majority of recent studies on invasive fungal infection have centred on general diagnosis and management of invasive fungal infection with only a brief commentary on cardiac involvement. The consequence of the lack of studies is belated diagnosis and relatively poor knowledge about fungal pathogenicity and virulence factors, which are key factors implicated in the ominous prognosis of FCM as well as its significant morbidity and mortality in affected patients. To appreciate the exact health burden of FCM, future prospective clinical trials should focus on evaluating the rate of dissemination, clinical findings and outcomes that will determine the current incidence of myocardial infection by fungi pathogens.

Diagnosis of myocardial fungal infection in the setting of disseminated fungal disease remains problematic. Even with the introduction of newer diagnostic methods including microbiological and radiographic into routine clinical practice, early diagnosis 
remains challenging yet its key to effective treatment. Initially, autopsy analysis confirmed a majority of cases of cardiac fungal infection, with clinical and autopsy diagnosis differing by over $44 \%[175,176]$. The difference has since reduced to $9 \%$ and even $0 \%$ in some hospital setting correlating with reducing research focus on autopsy analysis [8]. However, autopsy studies are still useful in assisting our understanding of the pathogenesis of fungal infection as well as continue to play an important role in identifying fungal disease. Prospective studies enrolling patients with fungal MC and FCM are warranted to facilitate development of better non-invasive imaging criteria for detecting fungal infection of the myocardium and cardiac dysfunction. Finally, studies on the effect of antifungal therapy on patients with fungal MC and FCM would improve management of these patients, who currently lack standardized treatment guidelines.

\section{Conclusion}

Invasive fungal infection in immunodeficient patients is potentially fatal but remains under-appreciated. A comprehensive understanding of invasive fungal infection and pathogenesis of cardiac involvement is not well documented as well as not properly understood largely because it is a grossly underresearched aetiology of infectious cardiomyopathy relative to viral and bacterial aetiologies. However, with increasing populations of immunocompromised patients - those with cancer, HIV/AIDS, and those receiving immunosuppressive treatment, and bone marrow and solid organ transplants - the incidence of invasive fungal infection will continue to increase as well as interfere with the proven efficacy of current treatment in these patients. Fungal cardiomyopathy (FCM) is an uncommon myocardial infection in the setting of disseminated fungal disease associated with significant morbidity and mortality. Its main causative fungal pathogens are Candida and Aspergillus species although Cryptococcus, Histoplasma, Blastomyces and Coccidioides may also cause the disease. The main risk factors for developing FCM is immunodeficiency and modern medical therapy including transplant recipients and prolonged corticosteroids, antibiotics and immunosuppressive therapies. Diagnosis is complicated by absent or ambiguous clinical findings of myocardial involvement and usually negative blood culture tests. However, a combination of tests microscopy, mycological culture, antigen and antibody detection, molecular diagnostics, and non-invasive imaging. Treatment for myocardial fungal infection is unclear, since it lacks standardized guidelines. However, prophylactic and therapeutic use of antifungal drugs is recommended for patients with invasive fungal infection. Current evidence on invasive fungal infection does not specifically focus on heart in particular myocardial involvement, and thus, the bulk of the evidence supporting the present discussion comes from either early autopsy studies, case reports as well as recent studies that focused on invasive fungal infection in general. The paucity of studies on FCM warrants future prospective studies that focus on fungal infections of the myocardium to refine the understanding of the pathogenicity of FCM including its diagnosis and clinical management.

\section{References}

1. Brown GD, Denning DW, Gow NA, Levitz SM, Netea MG et al. (2012) Hidden killers: human fungal infections. Sci Transl Med 4: 165rv13. [Crossref]

2. Bongomin F, Gago S, Oladele R, Denning D (2017) Global and multi-national prevalence of fungal diseases: estimate precision. J Fungi 3: E57. [Crossref]

3. Armstrong-James D, Meintjes G, Brown GD (2014) A neglected epidemic: fungal infections in HIV/AIDS. Trends Microbiol 22: 120-127. [Crossref]
4. Ghosh PN, Fisher MC, Bates KA (2018) Diagnosing emerging fungal threats: a one health perspective. Front Genet 9: 376. [Crossref]

5. Head MG, Fitchett JR, Atun R, May RC (2014) Systematic analysis of funding awarded for mycology research to institutions in the UK, 1997-2010. BMJ Open 4: e004129. [Crossref]

6. Ravikant KT, Gupte S, Kaur M (2015) A review on emerging fungal infections and their significance. J Bacteriol Mycol 1: 9-11.

7. Brown GD, Denning DW, Levitz SM (2012) Tackling human fungal infections. Science 336: 647. [Crossref]

8. Nosanchuk JD (2002) Fungal myocarditis. Front Biosci; 7: D1423-D1438. [Crossref]

9. Hurley TD (1916) An unique lesion of the heart in systemic blastomycosis. J Med Res 33: 499-502. [Crossref]

10. Joachim H, Polayes SH (1940) Subacute endocarditis and systemic mycosis (monilia) JAMA 115: 205-208.

11. Cawley EP (1947) Aspergillosis and the aspergilli. Report of a unique case of the disease. Arch Intern Med 80: 423-434. [Crossref]

12. Zimmerman LE (1950) Candida and Aspergillus endocarditis. With comments on the role of antibiotics in dissemination of fungus disease. Arch Pathol 50: 591-605. [Crossref]

13. Walsh TJ, Hutchins GM, Bulkley BH, Mendelsohn G (1980) Fungal infections of the heart: analysis of 51 autopsy cases. Am J Cardiol 45: 357-366. [Crossref]

14. Hutter RV, Collins HS (1962) The occurrence of opportunistic fungus infections in a cancer hospital. Lab Invest 11: 1035-1045. [Crossref]

15. Roberts WC, Bodey GP, Wertlake PT (1968) The heart in acute leukaemia. A study of 420 autopsy cases. Am J Cardiol 21, 388-412. [Crossref]

16. Kaul S, Fishbein MC, Siegel RJ (1991) Cardiac manifestations of acquired immune deficiency syndrome: a 1991 update. Am Heart $J$ 122: 535-544. [Crossref]

17. Rerkpattanapipat P, Wongpraparut N, Jacobs LE, Kotler MN (2000) Cardiac manifestations of acquired immunodeficiency syndrome. Arch Intern Med 160 602608. [Crossref]

18. Fisher SD, Lipshultz SE (2001) Epidemiology of cardiovascular involvement in HIV disease and AIDS. Ann NY Acad Sci 946: 13-22. [Crossref]

19. Craig JM, Farber S (1953) The development of disseminated visceral mycosis during therapy for acute leukemia. Am J Pathol 29: 601-601.

20. Zimmerman LE (1955) Fatal fungus infections complicating other diseases. Am J Clin Pathol 25: 46-65. [Crossref]

21. Keye JD, Magee WE (1956) Fungal diseases in a general hospital. A study of 88 patients. Am J Clin Pathol 26: 1235-1253. [Crossref]

22. Baker RD (1962) Leukopenia and therapy in leukemia as factors predis posing to fata mycoses. Mucormycosis, aspergillosis, and cryptococcosis Am J Clin Pathol 37: 358373. [Crossref]

23. Currie BP, Casadevall A (1994) Estimation of the prevalence of cryptococcal infection among patients infected with the human immunodeficiency virus in New York City. Clin Infect Dis 19: 1029-1033. [Crossref]

24. Mitchell TG, Perfect JR (1995) Cryptococcosis in the era of AIDS--100 years after the discovery of Cryptococcus neoformans. Clin Microbiol Rev 8: 515-548. [Crossref]

25. Powderly WG (2000) Cryptococcal meningitis in HIV-infected patients. Curr Infect Dis Rep 2: 352-357. [Crossref]

26. Ampel NM (1996) Emerging disease issues and fungal pathogens associated with HIV infection. Emerg Infect Dis 2: 109-116. [Crossref]

27. Minamoto GY, Rosenberg AS (1997) Fungal infections in patients with acquired immunodeficiency syndrome. Med Clin North Am 81: 381-409. [Crossref]

28. Launay O, Lortholary O, Bouges-Michel C, Jarrousse B, Bentata M et al. (1998) Candidemia: a nosocomial complication in adults with late-stage AIDS. Clin Infect Dis 26: 1134-1141. [Crossref]

29. Woitas RP, Rockstroh JK, Theisen A, Leutner C, Sauerbruch T et al. (1998) Spengler U. Changing role of invasive aspergillosis in AID: a case control study. J Infect 37: 116-122. [Crossref]

30. Tumbarello M, Tacconelli E, de Gaetano Donati K, Morace G etal. (1999) Candidemia in HIV-infected subjects. Eur J Clin Microbiol Infect Dis 18: 478-483. [Crossref] 
31. Bansod S, Rai M (2008) Emerging of mycotic infection in patients infected with Mycobacterium tuberculosis. World J Med Sci 3: 74-78.

32. Badiee P, Hashemizadeh Z (2014) Opportunistic invasive fungal infections: diagnosis \& clinical management. Indian J Med Res 139: 195-204. [Crossref]

33. Zimmerman LE (1950) Candida and Aspergillus endocarditis, with comments on the role of antibiotics in dissemination of fungus disease. AMA Arch. Pathol 50: 591-605. [Crossref]

34. Woods JW, Manning IH, Patterson CN (1951) Monilial infections complicating the therapeutic use of antibiotics. J Am Med Assoc 145: 207-211. [Crossref]

35. Hart PD, Russell E, Remington JS (1969) The compromised host and infection. II. Deep fungal infection. J Infect Dis 120: 169-191. [Crossref]

36. Seelig MS (1966) The role of antibiotics in the pathogenesis of Candida infections. Am J Med 40: 887-917. [Crossref]

37. Kligman AM (1952) Are fungus infections increasing as a result of antibiotic therapy? J Am Med Assoc 149: 979-983. [Crossref]

38. Brown C, Propp S, Guest CM, Beebe RT, Early L (1953) Fatal fungus infections complicating antibiotic therapy. $J$ Am Med Assoc 152: 206-207. [Crossref]

39. Torack RM (1957) Fungus infections associated with antibiotic and steroid therapy. $\mathrm{Am}$ J Med 22: 872-882. [Crossref]

40. Sidransky H, Pearl MA (1961) Pulmonary fungus infections associated with steroid and antibiotic therapy. Diseases of the Chest 39: 630-642.

41. Chatty ME, Deodhar SD (1969) Myocardial changes and kidney transplantation Lesions in patients receiving immunosuppressive therapy. Arch Pathol 88: 602-608. [Crossref]

42. Ribes JA, Vanover-Sams CL, Baker DJ (2000) Zygomycetes in human disease. Clin Microbiol Rev 13: 236-301. [Crossref]

43. Baddley JW (2011) Clinical risk factors for invasive aspergillosis. Med Mycol 49: S712. [Crossref]

44. Richardson MD (2005) Changing patterns and trends in systemic fungal infections. $J$ Antimicrob Chemother 56: i5-i11. [Crossref]

45. Perfect JR, Casadevall A (2006) Fungal molecular pathogenesis: what can it do and why do we need it? In Molecular principles of fungal pathogenesis, pp. 3-11. American Society of Microbiology.

46. Karkowska-Kuleta J, Rapala-Kozik M, Kozik A (2009) Fungi pathogenic to humans: molecular bases of virulence of Candida albicans, Cryptococcus neoformans and Aspergillus fumigatus. Acta Biochim Pol 56: 211-224. [Crossref]

47. Mavor AL, Thewes S, Hube B (2005) Systemic fungal infections caused by Candida species: epidemiology, infection process and virulence attributes. Curr Drug Targets 6: 863-874. [Crossref]

48. Chandra J, Kuhn DM, Mukherjee PK, Hoyer LL, McCormick T et al. (2001) Biofilm formation by the fungal pathogenCandida albicans: development, architecture, and drug resistance. J Bacteriol 183: 5385-5394. [Crossref]

49. Brown AJ, Odds FC, Gow NA (2007) Infection-related gene expression in Candida albicans. Curr Opin Microbiol 10: 307-313. [Crossref]

50. Chaffin WL, Lopez-Ribot JL, Casanova M, Gozalbo D, Martínez JP (1998) Cell wall and secreted proteins of Candida albicans: identification, function, and expression. Microbiol. Mol. Biol. Rev 62: 130-180. [Crossref]

51. Gore I, Saphir O (1947) Myocarditis: a classification of 1402 cases. Am Heart J 34 827-830. [Crossref]

52. Gruhn JG, Sanson J (1963) Mycotic infections in leukemic patients at autopsy. Cancer 16: 61-73. [Crossref]

53. Ihde DC, Roberts WC, Marr KC, Brereton HD, McGuire WP et al. (1978). Cardiac candidiasis in cancer patients. Cancer 41: 2364-2371. [Crossref]

54. Franklin WG, Simon AB, Sodeman TM (1976) Candida myocarditis without valvulitis. Am J Cardiol 38, 924-928. [Crossref]

55. Bernhardt HE, Orlando JC, Benfield JR, Hirose FM, Foos RY (1972) Disseminated candidiasis in surgical patients. Surg Gynecol Obstet 134: 819-825. [Crossref]

56. Parker, J.C., Jr. (1980) The potentially lethal problem of cardiac candidosis. Am J Clin Pathol 73: 356-361. [Crossref]

57. Atkinson JB, Robinowitz M, McAllister HA, Forman MB, Virmani R (1984) Cardiac infections in the immunocompromised host. Cardiol Clin 2: 671-686. [Crossref]
58. Atkinson JB, Connor DH, Robinowitz M, McAllister HA, Virmani R (1984) Cardiac fungal infections: review of autopsy findings in 60 patients. Human Pathol 15: 935 942. [Crossref]

59. Fine I, Brainerd H, Sokolow M (1950) Myocarditis in acute infectious diseases. A clinical and electrocardiographic study. Circulation 2: 859-871. [Crossref]

60. Van Kirk JE, Simon AB, Armstrong WR (1974) Candida myocarditis causing complete atrioventricular block. JAMA 227: 931-933. [Crossref]

61. Clancy CJ, Nguyen MH (1998) Acute community-acquired pneumonia due to Aspergillus in presumably immunocompetent hosts: clues for recognition of a rare but fatal disease. Chest 114: 629-634. [Crossref]

62. Tekaia F, Latge JP (2005) Aspergillus fumigatus: saprophyte or pathogen? Curr Opin Microbiol 8: 385-392. [Crossref]

63. Rementeria A, Lopez-Molina N, Ludwig A, Vivanco AB, Bikandi J et al. (2005) Gene and molecules involved in Aspergillus fumigatus virulence. Rev Iberoam Micol 22: 1-23. [Crossref]

64. Alp S, Arikan S (2008) Investigation of extracellular elastase, acid proteinase and phospholipase activities as putative virulence factors in clinical isolates of Aspergillus species. J Basic Microbiol 48: 331-337. [Crossref]

65. Denning DW (1998) Invasive Aspergillosis. Clin Infect Dis 26: 781-803. [Crossref]

66. Patterson TF, Kirkpatrick WR, White M, Hiemenz JW, Wingard JR (2000) Invasive aspergillosis. Disease spectrum, treatment practices, and outcomes. I3 Aspergillus Study Group. Medicine (Baltimore) 79: 250-260. [Crossref]

67. Safir, O (1942) Myocarditis. Arch Pathol 33: 88-137.

68. Ellis ME, Al-Abdely H, Sandridge A, Greer W, Ventura W (2001) Fungal endocarditis evidence in the world literature, 1965-1995. Clin Infect Dis 32: 50-62. [Crossref]

69. Hofman P, Gari-Toussaint M, Bernard E, Michiels JF, Gibelin P et al. (1992) Fungal myocarditis in acquired immunodeficiency syndrome. Arch Mal Coeur Vaiss 85: 203208. [Crossref]

70. Bodey GP (1966) Fungal infections complicating acute leukaemia. J Chronic Dis 19 667-687. [Crossref]

71. Gerson S, Talbot G, Hurwitz S, Strom B, Lusk E et al. (1984) Prolonged granulocytopenia: the major risk factor for invasive pulmonary aspergillosis in patients with acute leukemia. Ann Intern Med 100: 345-351. [Crossref]

72. Pizzo P, Robichaud K, Gill F, Witebsky F (1982) Empiric antibiotic and antifunga therapy for cancer patients with prolonged fever and granulocytopenia. Am J Med 72: 101-111. [Crossref]

73. Young R, Bennett J, Vogel C, Carbone P, DeVita V (1970) Aspergillosis: the spectrum of disease in 98 patients. Medicine 49: 147-173. [Crossref]

74. Grcevic N, Matthews W (1959) Pathologic changes in acute disseminated aspergillosis Am J Clin Pathol 32: 536-551. [Crossref]

75. Luke J, Bolande R, Gross (1963) Generalized aspergillosis and Aspergillus endocarditis in infancy. Peds 31: 115-122. [Crossref]

76. Williams AH (1974) Aspergillus myocarditis. Am J Clin Pathol 61: 247-256. [Crossref]

77. Schwartz DA (1989) Aspergillus pancarditis following bone marrow transplantation for chronic myelogenous leukemia. Chest 95: 1338-1339. [Crossref]

78. Walsh TJ, Hutchins GM (1979) Aspergillus mural endocardits. Am J Clin Pathol 71: 640-644. [Crossref]

79. Buchbinder NA, Roberts WC (1972) Active infective endocarditis confined to mura endocardium. A study of six necropsy patients. Arch Pathol 93: 435-440. [Crossref]

80. Welsh R, Buchness J (1955) Aspergillus endocarditis, myocarditis and lung abscess report of a case. Am J Clin Pathol 25: 782-786. [Crossref]

81. Carbone P, Sabesin S, Sidransky H, Frei EI (1964) Secondary aspergillosis. Ann Intern Med 60: 556-567. [Crossref]

82. Andersson BS, Luna MA, McCredie KB (1986) Systemic aspergillosis as cause of myocardial infarction. Cancer 58: 2146-2150. [Crossref]

83. Rogers JG, Windle JR, McManus BM, Easley AR (1990) Aspergillus myocarditis presenting as myocardial infarction with complete heart block. Am Heart $J$ 120: 430432. [Crossref]

84. Goldstein E. Rambo D (1962) Cryptococcal infection following steroid therapy. Ann Intern Med 56: 114-120. [Crossref]

85. Bennington J, Harber S, Morgenstern N (1964) Increased susceptibility of cryptococcosis following steroid therapy. Dis Chest 45: 262-263. [Crossref] 
86. Zimmerman L, Rappaport H (1954) Occurance of cryptococcosis in patients with malignant disease of the reticuloendothelial system. Am J Clin Pathol 24: 10501072. [Crossref]

87. Casadevall A, Perfect JR (1998) Cryptococcus neoformans. American Society for Microbiology, Washington, DC.

88. Park BJ, Wannemuehler KA, Marston BJ, Govender N, Pappas PG et al. (2009) Estimation of the current global burden of cryptococcal meningitis among persons living with HIV/AIDS. AIDS 23: 525-530. [Crossref]

89. Husain S, Wagener MM, Singh N (2001) Cryptococcus neoformans infection in organ transplant recipients: variables influencing clinical characteristics and outcome. Emerg Infect Dis 7: 375-381. [Crossref]

90. Perfect JR (2006) Cryptococcus neoformans: a sugar-coated killer. In Molecular principles of fungal pathogenesis. Heitman J, Filler SG, Edwards JE Jr, Mitchell AP, Eds, pp. 281-303. ASM Press, Washington DC

91. Littman M, Zimmerman L (1956) Cryptococcosis, torulosis or European blastomycosis. Grune \& Stratton, New York.

92. Jones I, Nassau E, Smith P (1965) Cryptococcosis of the heart. Brit Heart J 27: 462 464. [Crossref]

93. Cammarosano C, Lewis W (1985) Cardiac lesions in acquired immune deficiency syndrome (AIDS). J Am Coll Cardiol 5: 703-706. [Crossref]

94. Lewis W, Lipsick J, Cammarosano C (1985) Cryptococcal myocarditis in acquired immune deficiency syndrome. Am J Cardiol 55: 1240. [Crossref]

95. Lafont A, Marche C, Wolfe M, Perrone C, Witchitz S et al. (1988) Myocarditis in acquired immunodeficiency syndrome (AIDS): etiology and prognosis. $J$ Am Coll Cardiol 11: 196A.

96. Lafont A, Wolff M, Marche C, Clair B, Regnier B (1987) Overwhelming myocarditis due to Cryptococcus neoformans in an AIDS patient. Lancet 2: 1145-1146. [Crossref]

97. Buchanan KL, Murphy JW (1998) What makes Cryptococcus neoformans a pathogen? Emerg Infect Dis 4: 71-83. [Crossref]

98. Bradsher RW (1996) Histoplasmosis and Blastomycosis Clin Infect Dis 22: S102-111. [Crossref]

99. Cano MV, Hajjeh RA (2001) The epidemiology of histoplasmosis: a review. Semin Respir Infect 16: 109-118. [Crossref]

100. Kauffman CA (2007) Histoplasmosis: a clinical and laboratory update. Clin Microbiol Rev 20: 115-132. [Crossref]

101. Dodd K, Tompkins E (1934) Case of histoplasmosis of Darling in an infant. Am J Trop Med 14: 127-137.

102. Humphrey A (1940) Reticuloendothelial cytomycosis (histoplasmosis of Darling). Arch Intern Med 65: 902-918.

103. Kuzma J (1947) Histoplasmosis: The pathologic and clinical findings. Dis Chest 13: 338-344. [Crossref]

104. Prager RL, Burney DP, Waterhouse G, Bender HW (1980) Pulmonary, mediastinal, and cardiac presentations of histoplasmosis. Ann Thorac Surg 30: 385390. [Crossref]

105. Anderson DW, Virmani R, Reilly JM, O’Leary T, Cunnion RE et al. (1988) Prevalent myocarditis at necropsy in the acquired immunodeficiency syndrome. $J$ Am Coll Cardiol 11: 792-799. [Crossref]

106. Marcher A (1988) The pathology of AIDS. Public Health Rep 103: 246-254. [Crossref]

107. Wheat LJ, Chetchotisakd P, Williams B, Connolly P, Shutt K, Hajjeh R (2000) Factors associated with severe manifestations of histoplasmosis in AIDS. Clin Infect Dis 30: 877-881. [Crossref]

108. Merchant R, Louria DB, Geisler P, Edgcomb J, Utz J (1958) Fungal endocarditis: review of the literature and report of three cases. Ann Intern Med 48: 242-266. [Crossref]

109. Binford C (1955) Histoplasmosis: tissue reactions and morphologic variations of the fungus. Am J Clin Pathol 25: 25-36. [Crossref]

110. Zimmerman L (1957) Some contibutions of the histopathological method to the study of fungus disease. Tr New York Acad Sc 19: 358-371. [Crossref]

111. Altieri PI, Climent C, Lazala G, Velez R, Torres JV (1994) Opportunistic invasion of the heart in Hispanic patients with acquired immunodeficiency syndrome. Am J Trop Med Hyg 51: 56-59. [Crossref]
112. Saccente M, Woods GL (2010) Clinical and laboratory update on blastomycosis Clinical Microbiology Reviews 23: 367-381. [Crossref]

113. Gnann JW, Bressler GS, Bodet CA, Avent CK (1983) Human blastomycosis after a dog bite. Ann Intern Med 98: 48-49. [Crossref]

114. Bradsher RW, Martin MR, Wilkes TD, Waltman C, Bolyard K (1990) Unusual presentations of blastomycosis: ten case summaries. Infections in Surgery 9: 10-19.

115. Cleary J (1904) A case of generalized Blastomycosis. Medicine 10: 818-823.

116. Busey J, Baker R, Birch L, Buechner H, Chick E et al. (1964) Blastomycosis. I. A review of 198 collected cases in Veterans Administration hospitals. Am Rev Respir Dis 89: 659-672. [Crossref]

117. Baker RD, Brian EW (1937) Blastomycosis of the heart. Am J Pathol 13: 139-147. [Crossref]

118. Pond N, Humphreys R (1952) Blastomycosis with cardiac involvement and peripheral embolization. Am Heart J 43: 615-620. [Crossref]

119. Harding C (1991) Blastomycosis and opportunistic infections in patients with acquired immunodeficiency syndrome. An autopsy study. Arch Pathol Lab Med 115 : 1133-1136. [Crossref]

120. Pappas P, Pottage J, Powderly WG, Fraser V, Stratton C et al. (1992) Blastomycosis in patients with the acquired immunodeficiency syndrome. Ann Intern Med 116: 847853. [Crossref]

121. Martin D, Smith D (1939) Blastomycosis (American blastomycosis, Gilchrist's disease): I. A review of the literature. Am Rev Tuberc 40: 275-304.

122. Laniado-Laborin R, Alcantar-Schramm JM, Cazares-Adame R (2012) Coccidioidomycosis: an update. Current Fungal Infection Reports 6: 113-120.

123. Stevens DA, Clemons KV, Levine HB, Pappagianis D, Baron EJ et al. (2009) Expert opinion: what to do when there is Coccidioides exposure in a laboratory. Clin Infect Dis 49: 919-923. [Crossref]

124. DiCaudo DJ (2006) Coccidioidomycosis: a review and update. J Am Acad Dermatol 55: 929-942. [Crossref]

125. Forbus W, Bestebreurtje A (1946) Coccidioidomycosis: a study of 95 cases of disseminated type with special reference to the pathogenesis of the disease. Milit Surg 99: 653-719. [Crossref]

126. Chapman M, Kaplan L (1957) Cardiac involvement in cocidioidomycosis. Am J Med 23: 87-98. [Crossref]

127. Huntington R (1977) Acute fatal coccidioidal pneumonia. In Coccidioidomycosis Current clinical and diagnostic status. Ed. Ajello,L, Symposia Specialists, Miami, F1. 127137.

128. Singh,V. Smith D, Lawrence J, Kelly P, Thomas A et al. (1996) Coccidioidomycosis in patients infected with human immunodeficiency virus: review of 91 cases at a single institution. Clin Infect Dis 23: 563-568. [Crossref]

129. Bronnimann D, Adam RD, Galgiani JN, Habib M, Petersen EA et al. (1987) Coccidioidomycosis in the Acquired Immunodeficiency Syndrome. Ann Intern Med 106: 372-379. [Crossref]

130. Tudbury $\mathrm{P}$ (1955) The electrocardiogram in primary coccidioidomycosis. Calif Med 83: 89-90. [Crossref]

131. Schwartz EL, Waldmann EB, Payne RM, Goldfarb D, Kinard SA (1976) Coccidioida pericarditis. Chest 70: 670-672. [Crossref]

132. Blankenhorn MA, Gall EA (1956) Myocarditis and myocardosis: a clinicopathologic appraisal. Circulation 13: 217-223. [Crossref]

133. Chinen K, Tokuda Y, Sakamoto A, Fujioka Y (2007) Fungal infections of the heart a clinicopathologic study of 50 autopsy cases. Pathol Res Pract 203: 705-715. [Crossref]

134. Larbcharoensub N, Srisuma S, Ngernprasertsri T, Aroonroch R, Chongtrakool P et al (2007) Invasive fungal infection in Ramathibodi Hospital: a ten-year autopsy review. J Med Assoc Thai 90: 2630-2637. [Crossref]

135. Uppin MS, Anuradha SV, Uppin SG, Paul TR, Prayaga AK, Sundaram C (2011) Fungal infections as a contributing cause of death: an autopsy study. Indian J Pathol Microbiol 54: 344-349. [Crossref]

136. Lewis RE, Cahyame-Zuniga L, Leventakos K, Chamilos G, Ben-Ami R et al. (2013) Epidemiology and sites of involvement of invasive fungal infections in patients with haematological malignancies: a 20-year autopsy study. Mycoses 56: 638-645. [Crossref] 
137. Gupta R, Malik A, Rizvi M, Ahmed M (2016) An Alarming Increase of Fungal Infections in Intensive Care Unit: Challenges in the Diagnosis and Treatment. $J$ Appl Pharm Sci 6: 114-119.

138. Shen YZ, Qi TK, Ma JX, Jiang XY, Wang JR et al. (2007) Invasive fungal infections among inpatients with acquired immune deficiency syndrome at a Chinese university hospital. Mycoses 50: 475-480. [Crossref]

139. Wadhwa A, Kaur R, Agarwal SK, Jain S, Bhalla P (2007) AIDS-related opportunistic mycoses seen in a tertiary care hospital in North India. J Med Microbiol 56: 11011106. [Crossref]

140. Badiee P, Kordbacheh P, Alborzi A, Malekhoseini S, Ramzi M et al. (2009) Study on invasive fungal infections in immunocompromised patients to present a suitable early diagnostic procedure. Int J Infect Dis 13: 97-102. [Crossref]

141. Kaur R, Dhakad MS, Goyal R, Bhalla P, Dewan R (2016) Spectrum of opportunistic fungal infections in HIV/AIDS patients in tertiary care hospital in India. Can J Infect Dis Med Microbiol 2016: 2373424. [Crossref]

142. Viscoli C, Girmenia C, Marinus A, Collette L, Martino P et al. (1999) Candidemia in cancer patients: a prospective, multicenter surveillance study by the Invasive Funga Infection Group (IFIG) of the European Organization for Research and Treatment of Cancer (EORTC). Clin Infect Dis 28: 1071-1079. [Crossref]

143. Chamilos G, Luna M, Lewis RE, Bodey GP, Chemaly R et al. (2006) Invasive fungal infections in patients with hematologic malignancies in a tertiary care cancer center: an autopsy study over a 15-year period (1989-2003). Haematologica 91: 986-989. [Crossref]

144. Pagano L, Caira M, Candoni A, Offidani M, Fianchi L et al. (2006) The epidemiology of fungal infections in patients with hematologic malignancies: the SEIFEM-2004 study. Haematologica 91: 1068-1075. [Crossref]

145. Degregorio MW, Lee WM, Linker CA, Jacobs RA, Ries CA (1982) Fungal infections in patients with acute leukemia. Am J Med 73: 543-548. [Crossref]

146. Martino R, Subirá M, Rovira M, Solano C, Vázquez L et al. (2002) Invasive fungal infections after allogeneic peripheral blood stem cell transplantation: incidence and risk factors in 395 patients. British journal of haematology 116: 475-482. [Crossref]

147. Harrison N, Mitterbauer M, Tobudic S, Kalhs P, Rabitsch W et al. (2015) Incidence and characteristics of invasive fungal diseases in allogeneic hematopoietic stem cell transplant recipients: a retrospective cohort study. BMC Infect Dis 15: 584. [Crossref]

148. Shi JM, Pei XY, Luo Y, Tan YM, Tie RX et al. (2015) Invasive fungal infection in allogeneic hematopoietic stem cell transplant recipients: single centre experiences of 12 years. J Zhejiang Univ Sci B 16: 796-804. [Crossref]

149. Patel MH, Patel RD, Vanikar AV, Kanodia KV, Suthar KS et al. (2017) Invasive fungal infections in renal transplant patients: a single centre study. Ren Fail 39: 294 298. [Crossref]

150. Bierman B, Bubalo $\mathbf{J}$ (2006) Invasive fungal infections in immunocompromised patients: a review of antifungal agents. US Pharm 1: 3-15.

151. Douglas LJ (2003) Candida biolms and their role in infection. Trends Microbiol 11: 30-36. [Crossref]

152. Pappas PG, Rex JH, Sobel JD, et al. (2004) Guidelines for treatment of candidiasis. Clin Infect Dis 38: 161-189. [Crossref]

153. Goodman JL, Winston DJ, Greenfield RA, Chandrasekar PH, Fox B et al. (1992) A controlled trial of fluconazole to prevent fungal infections in patients undergoing bone marrow transplantation. $N$ Engl J Med 326: 845-851. [Crossref]

154. Ruhnke M, Böhme A, Buchheidt D, Cornely O, Donhuijsen K et al. (2012) Diagnosis of invasive fungal infections in hematology and oncology--guidelines from the Infectious Diseases Working Party in Haematology and Oncology of the German Society for Haematology and Oncology (AGIHO). Ann Oncol 23: 823-833. [Crossref]

155. De Pauw B, Walsh TJ, Donnelly JP, Stevens DA, Edwards JE et al. (2008) Revised definitions of invasive fungal disease from the European organization for research and treatment of cancer/invasive fungal infections cooperative group and the national institute of allergy and infectious diseases mycoses study group (EORTC/MSG) consensus group. Clin Infect Dis 46: 1813-1821. [Crossref]
156. Subira M, Martino R, Rovira M et al. (2003) Clinical applicability of the new EORTC/MSG classification for invasive pulmonary aspergillosis in patients with hematological malignancies and autopsy-confirmed invasive aspergillosis. Ann Hematol 82: 80-82. [Crossref]

157. Chow LH, Radio SJ, Sears TD, Mcmanus BM (1989) Insensitivity of right ventricular endomyocardial biopsy in the diagnosis of myocarditis. $\mathrm{J} \mathrm{Am} \mathrm{Coll} \mathrm{Cardiol}$ Cardiology 14: 915-920. [Crossref]

158. Lie JT (1988) Myocarditis and endomyocardial biopsy in unexplained heart failure: a diagnosis in search of a disease. Ann Intern Med 109: 525-528. [Crossref]

159. Henochowicz S, Mustafa M, Lawrinson W, Pistole M, Lindsay JJ (1985) Cardiac aspergillosis in acquired immune deficiency syndrome. Am J Cardiol 55: 1239-1240. [Crossref]

160. Bernarducci L, Ford K, Olenick S, Devries S (1993) Invasive intracardiac aspergillosis with widespread embolization. J Am Soc Echocardiogr 6: 539-542. [Crossref]

161. Alam M, Higgins R, Alam Z, Janakiraman Z, Gorman M (1998) Aspergillus fungal mass detected by transesophageal echocardiography. J Am Soc Echocardiogr 11: 8385. [Crossref]

162. Donal E, Coisne D, Corbi P, Christiaens L, Allal J, Barraine R (1998) Candida albicans myocarditis or endocarditis? Echocardiographic aspects. Ann Cardiol Angeiol (Paris) 47, 465-468. [Crossref]

163. Lie JT (1988) Detection of acute myocarditis using nuclear magnetic resonance imaging. Am J Med 85: 282-283. [Crossref]

164. Roditi GH, Hartnell GG, Cohen MC (2000) MRI changes in myocarditis--evaluation with spin echo, cine MR angiography and contrast enhanced spin echo imaging. Clin Radiol 55: 752758. [Crossref]

165. Enoch DA, Ludlam HA, Brown NM (2006) Invasive fungal infections: a review of epidemiology and management options. J Med Microbiol 55: 809-818. [Crossref]

166. Rex JH, Walsh TJ, Sobel JD, Filler SG, Pappas PG et al. (2000) Practice guidelines for the treatment of candidiasis. Infectious Diseases Society of America. Clin Infect Dis 30: 662-678. [Crossref]

167. Marr KA (2001) Antifungal prophylaxis in hematopoietic stem cell transplant recipients. Oncology (Huntingt) 15: 15-19. [Crossref]

168. Marr KA (2002) Empirical antifungal therapy--new options, new tradeoffs. $N$ Engl J Med 346: 278-280. [Crossref]

169. Corey L, Boeckh M (2002) Persistent fever in patients with neutropenia. $N$ Engl J Med 346: 222-224. [Crossref]

170. Mousset S, Buchheidt D, Heinz W, Ruhnke M, Cornely OA et al.(2014) Treatment of invasive fungal infections in cancer patients - updated recommendations of the Infectious Diseases Working Party (AGIHO) of the German Society of Hematology and Oncology (DGHO) Ann Hematol 93: 13-32. [Crossref]

171. Kaufman D, Boyle R, Hazen KC, Patrie JT, Robinson M et al. (2001) Fluconazole prophylaxis againstfungal colonization and infection in preterm infants. $N$ Engl J Med 345: 1660-1666. [Crossref]

172. Hood S, Denning DW (1994) Treatment of fungal infection in AIDS. J Antimicrob Chemother 37: 71-85. [Crossref]

173. Schuman, P, Capps L, Peng G, Vazquez J, el-Sadr W, Goldman AI (1997) Weekly fluconazole for the prevention of mucosal candidiasis in women with HIV infection. A randomized, double-blind, placebocontrolled trial. Terry Beirn Community Programs for Clinical Research on AIDS. Ann Intern Med 126: 689-696. [Crossref]

174. Martin MV (2000) The use of fluconazole and itraconazole in the treatment of Candida albicans infections: a review. J Antimicrob Chemother 45: 555. [Crossref]

175. Nichols L, Aronica P, Babe C (1998) Are autopsies obsolete? Am J Clin Pathol 110: 210-218. [Crossref]

176. Burton EC, Troxclair DA, Newman III WP (1998) Autopsy diagnoses of malignant neoplasms: how often are clinical diagnoses incorrect? JAMA 280: 1245-1248. [Crossref]

Copyright: (C2019 Albakri A. This is an open-access article distributed under the terms of the Creative Commons Attribution License, which permits unrestricted use, distribution, and reproduction in any medium, provided the original author and source are credited. 